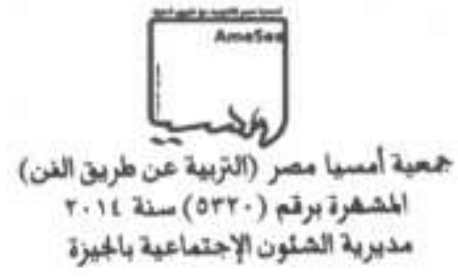

\title{
التناول الفكرى و الجمالى للظل فى النحت المعاصر
}

Handling intellectual and aesthetic shade in contemporary sculpture

$$
\text { أ.م.د/ حنان محمد على شرف اعداد }
$$

استاذ النحت المساعد بقسم التعبير المجسم ـ كلية التربية الفنية - جامعة حلوان

$$
p^{r+r l}
$$




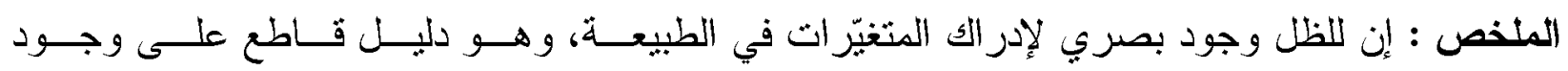

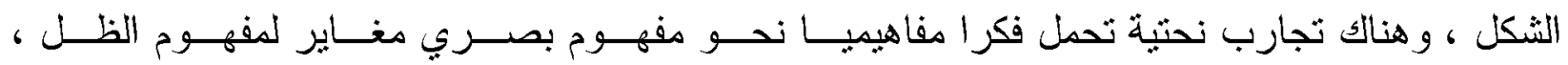

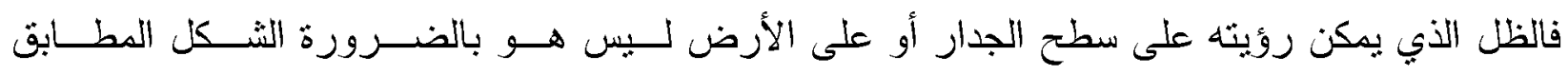

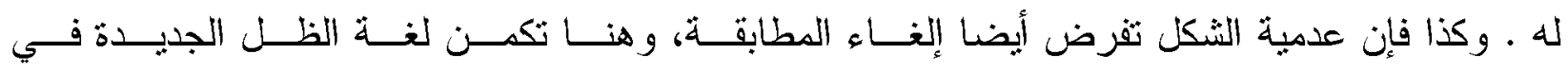

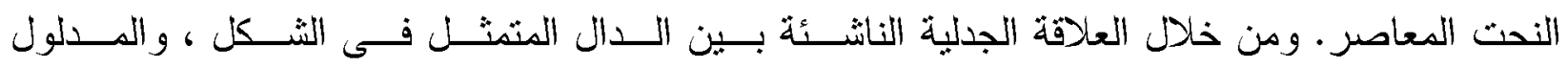

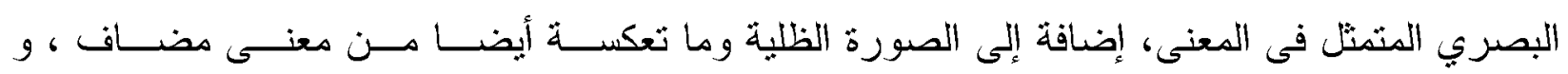

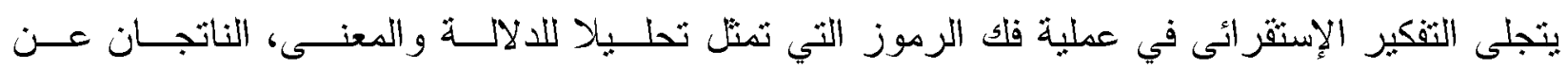

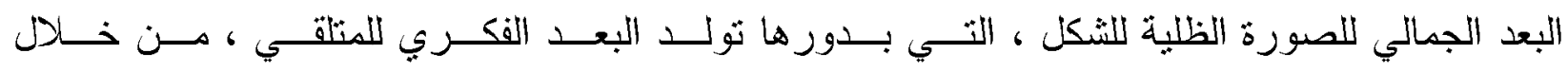

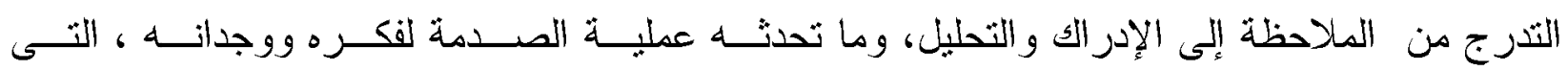

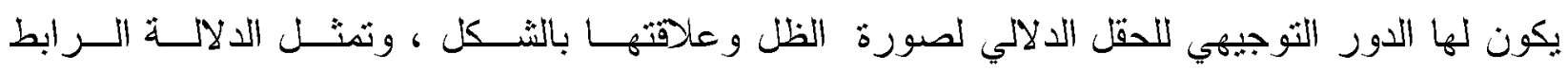

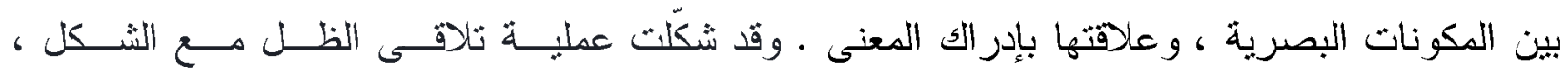

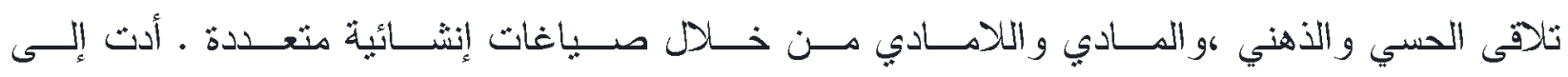

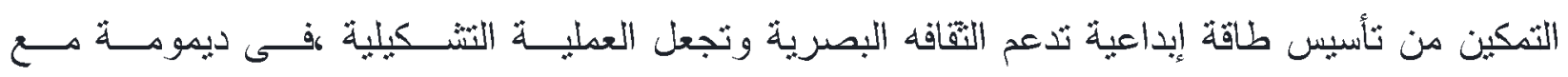

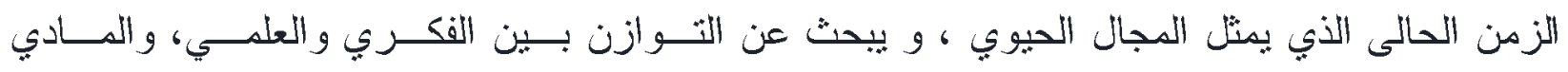
الحسي. مثكلة البحث : لم بعد الفن مرثبطا بمكان و لا زمان محدد ، و إنما تحول إلى عملية تجاوز للحدود الزمكانبة، استتادا إلـى

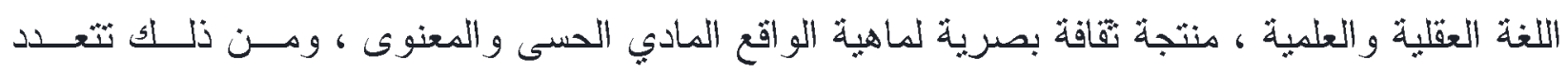

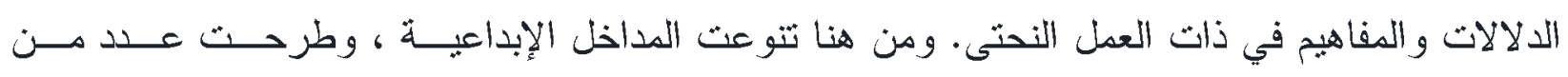
التساؤلات الفكرية والوجودية حول الثكل وخيال الظل ومحيطه وو اقعهة. وتكمن أسئلة البحث فى الآتى :

- ما هى فلسفة إيجاد حقل دلالى بصرى بين الثنكل بوجوده المادى وخيال ظلة اللامادى و الضوء ؟

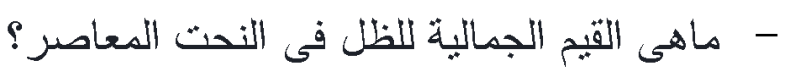

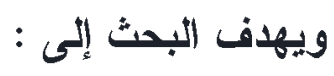
- الكثف عن التتاول الفكرى و الجمالى للظل فى النحت المعاصر - ثيان كيفبة نكوين المعنى بين النّكل وخبال الظل سواء كان مغاير أم مطابقا أم مفارقا..

\section{(AmeSea Database - ae - April- 2021- 0481)}


فروض البحث :

- يمكن أن تكون هناك ثتوع بالدالالة التعبيريه و الوعى بالمعنى بين الثكل وظلة .

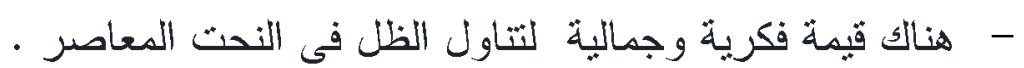

أهمية البحث

- فتح آفاق جديدة للتفكير و البناء من خلال استخدام الضوء والظل فى البناء النحتى المعاصر للتنديس بالكليات الفنبة .

- الكثف عن الأسس الإنثائية وما يتبعها من قيمة جمالية للظل فى فن النحت المعاصر فـى ضــوء الدلالات الخاصة به والمختلفة . منهج البحث يثبع البحث المنهج الوصفى التحليلى فى نتاول المفاهيم الفكرية الخاصة بالظل من خـلال

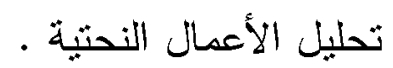

-مفهوم الظل صورة الظل نطوع الفكر والحس و البعد الزمني لدى المتلقي ، و هي الفاعلة في عملية

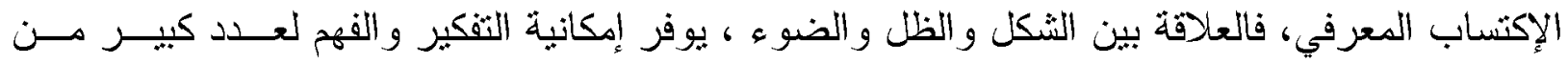

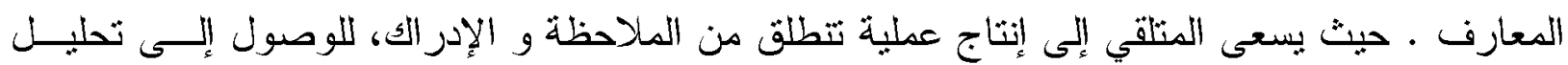

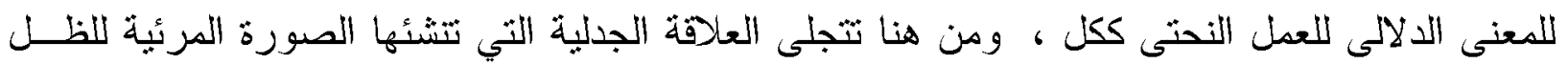
في ذاكرة المتلقي ، وتتأسس هذه العلاقة ضدن عمليات فكرية ونفسية وبصرية نقوم بعملية تأثير وتأثر ،

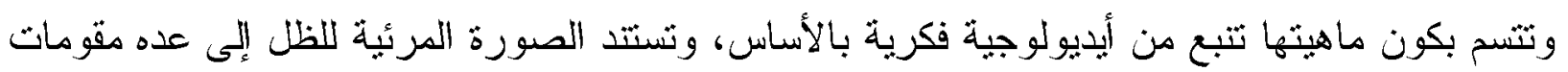

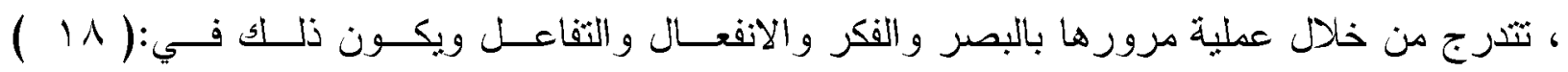

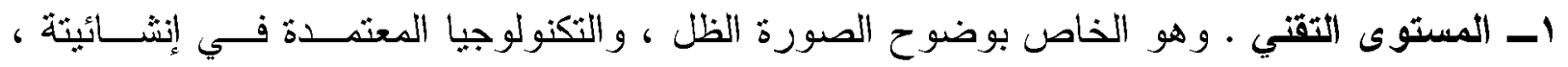

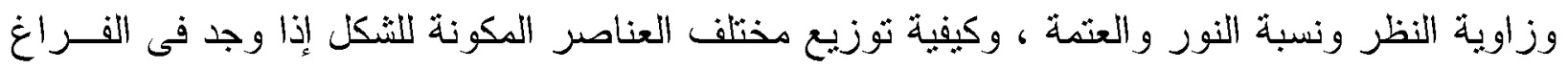
الركانى ، فهى عملية إخراج وتدقيق في التقنية .

rــ المستوى الجمالي .وهو الذى يولَّد البعد الجمالي في إنثاء صورة الظل القائم على الثركيب البنائي المنوازن للنكل وعلاقتة بالضوء ، وما يحويه من خصائص بصرية وتعبيرية ، ومقومات التذوق داخل

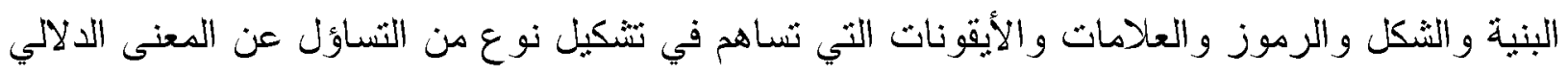
وتفسير الصورة الظلبة

(AmeSea Database - ae - April- 2021- 0481) 


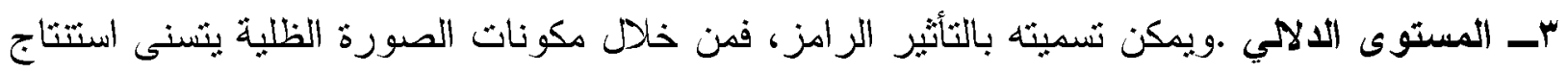

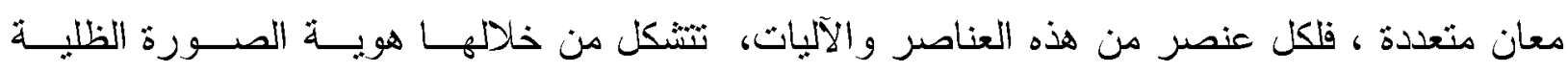

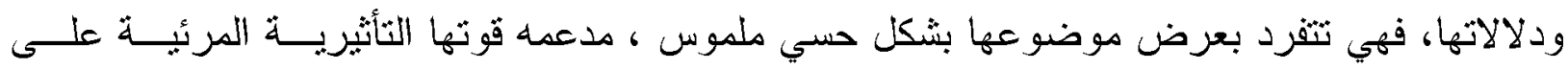
المنلقي.

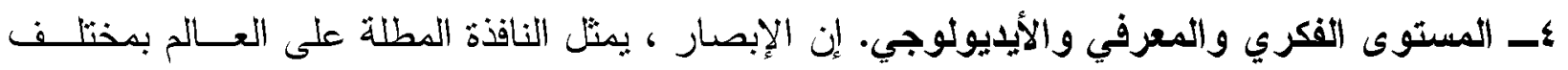

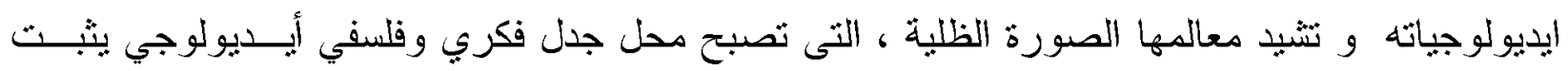

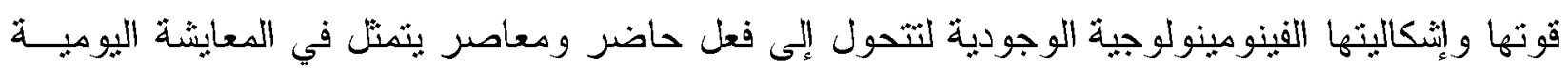

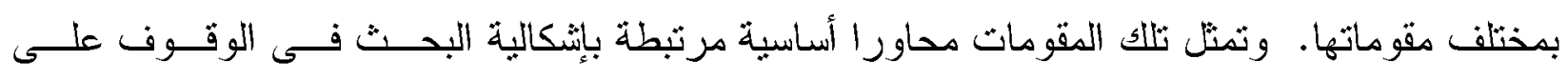
الجوانب الفكرية والإبداعية للظل فى النحت المعاصر، ومن ثم سوف يثم ثناولهم بالتفسير .

أولا :المستوى التقنى

1-المفاهيم المرتبطة بالظل ـ الثنكل وعلاقتة بالضوى

1-انظل.

أ-1 - فلسفة الظل ـ إذا قبس الظل بالعدم فإن الظل له لون من الوجود ولكن إذا قبس الظل بصاحب الظل فإنه لاشيء قياساً بصاحبه، وهكذا إذا أزيل الظل فإن ما يتبقى هو صاحب الظل (9 (1) إن مفهوم الظل مفهوم عميق ومتداخل مع فكرة الوجود المطلق والعدم.. مما يفتح المجال لإعادة التفكبــر فــي

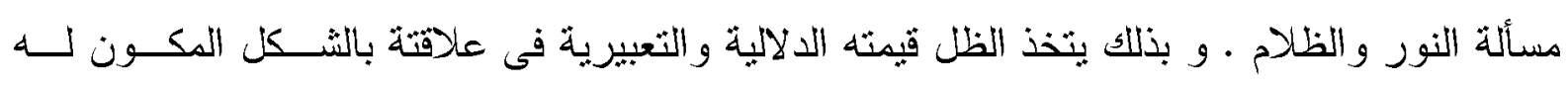
و الضوء .

أ-ب- بدايات الاهتمام بالظل ـ " في أوروبا خلال العصور الوسطى كانت ثتم ، معاقبة ظل النبيـلـل

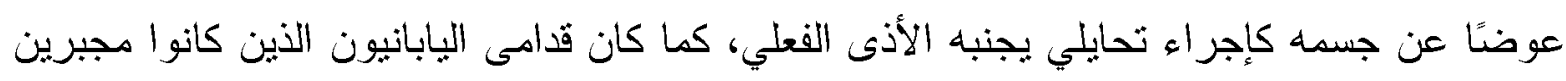

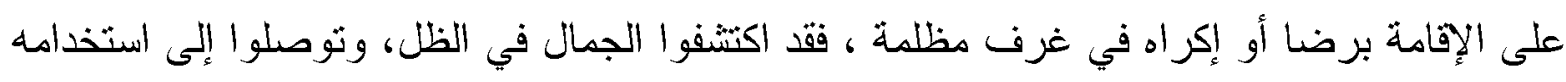

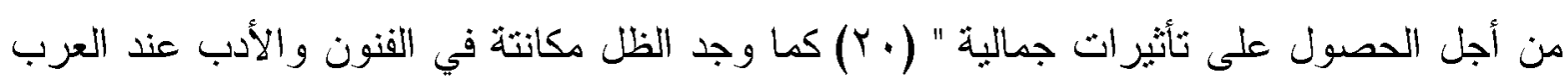

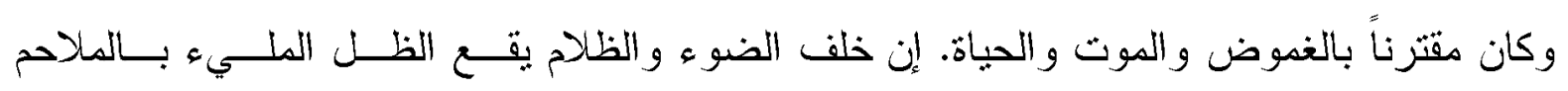

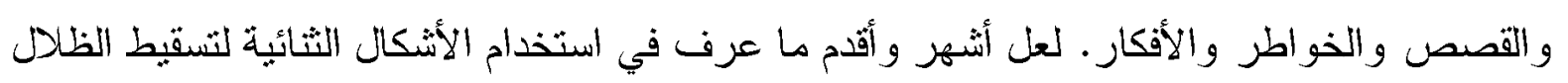
هو ما يعرف قديما وحديثا بـذيال الظل ، "حيث كان الصينيون القدامى أول من ابنكر هذه الطريقة

(AmeSea Database - ae - April- 2021- 0481) 


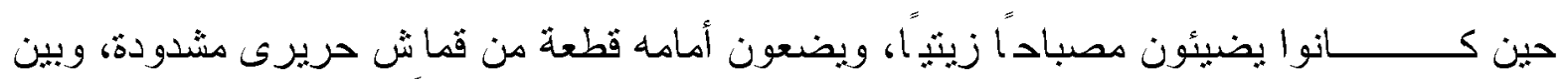

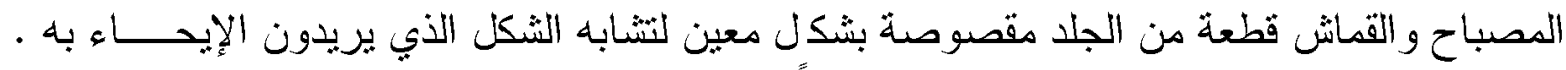
فلا يرى الناظر من الجهة الأخرى سوى خيال هذه القطعة" .(Y)

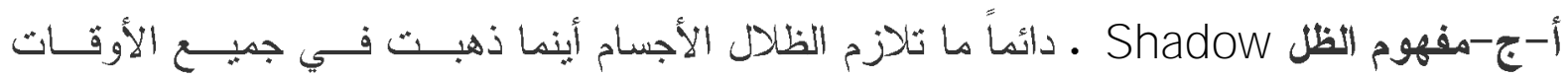
و الأزمان، ويُعتبر المصدر الرئبسى لظهور الظل هو الضّوء، ولذلك لاوجود له في الظلام ، وكذا عند

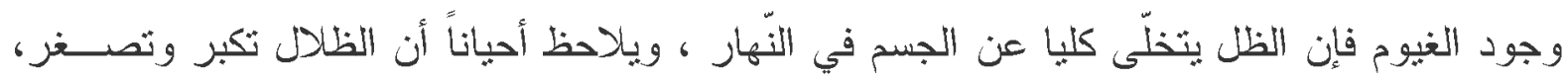

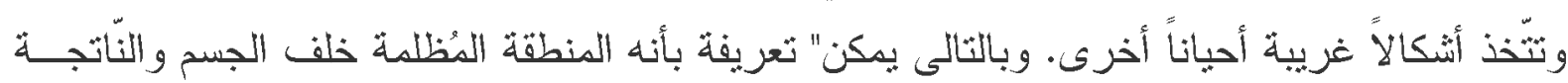

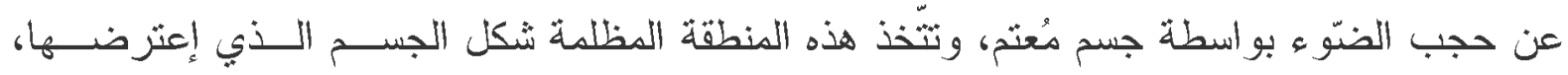
وتلازمة ما دام مصدر الضّوء موجوداً". (23) ويتضتح أن الظلّ يشمل الخيال الناتج عن الشكل فـي هده اتجاه سقوط أثعة الثمس · وإن السيطرة على تكوين الظل تعتبر بذلك ممارسة للعق لـل علـى إدراك الفراغ و السيطرة بشكل دقيق على أشكاله الممكنة و أساليب إظهارة المختلفة. لذلك فان فكـرة العمـلـل النحنى التابع لهذا الإتجاه تتبع في المقام الأول من خبرة وتجربة العقل.

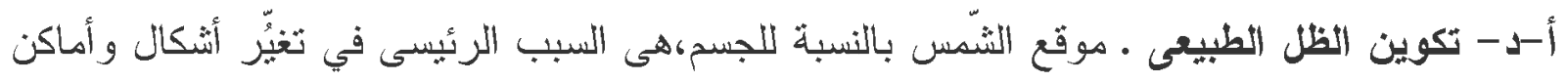

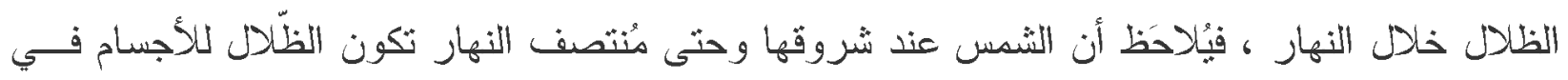

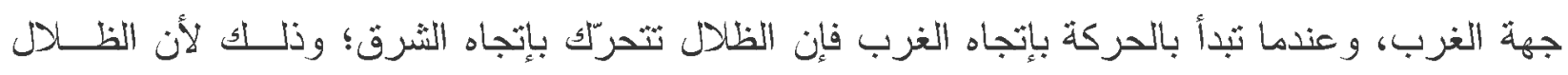

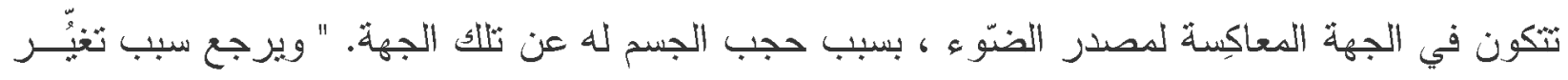

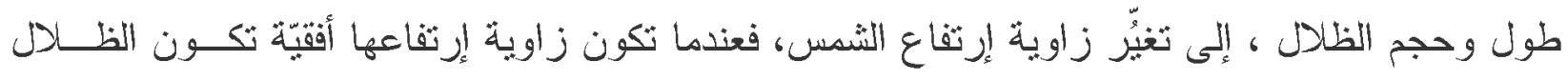
أطول ما يمكن، وذلك يحدث عند الثروق والغروب ، أما إذا كانت زاوية إرتفاع الثمس عموديــة فــان الظلال تكون أقصر ما يمكن، عند الظهيرة عندما تكون الشمس في مُنتصف السّماء."(22) ومــن خـلال ذلك يمكن ملاحظة أن ثنلاتية الضوء، الثكل ، الظل ، كل منهم دال للآخر، ومدلول في نفس الوقت ، فالثنمس مبعث الضوء، هي دليل الظل لكنه في نفس الوقت دال ، فمن طول الظل واتجاهه بمكن تحديـــ اتجاه الثثمس ، وارنقاعها وقياسا على ذلك ف فإن الثكل أو الجسم هوالدال على شكل الظل ، المنسوخ عنه، و أيضا الظل هو دال على شكل الجسم ، المسقط له ، وبالتالي كان كـلـ منهما دال على الآخر ومدلول له كما هو موضتح فى (شكل؛، r،r، 1)

(AmeSea Database - ae - April- 2021- 0481) 


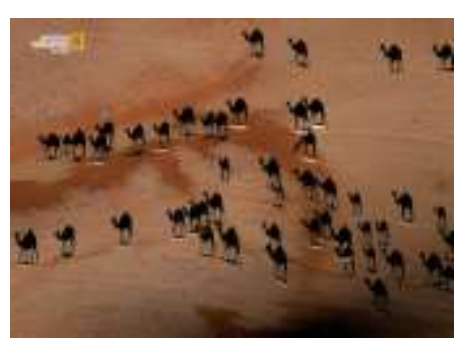

شكل(Y) الظل الاسود في أقصى طون له ـ الشكل هي الخطوط البيضاء (YT)

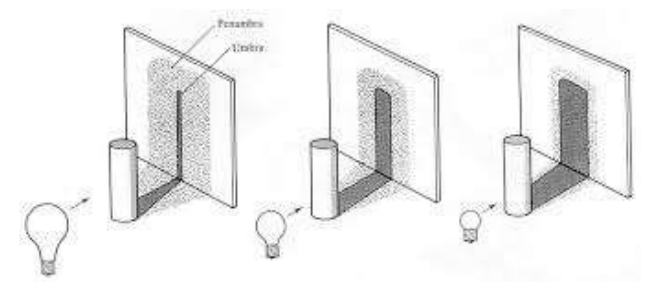

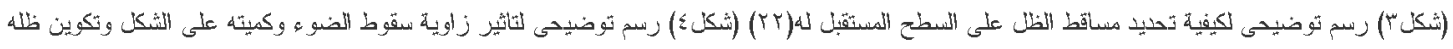
(YY)
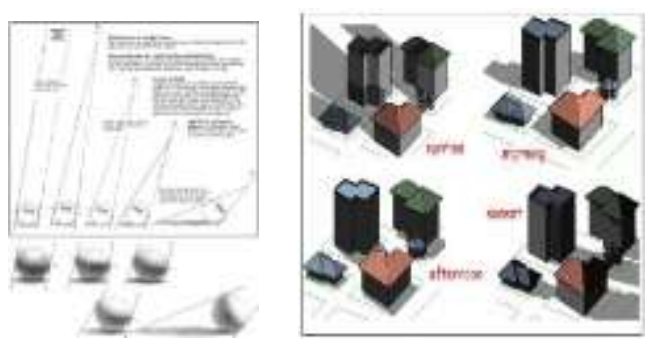

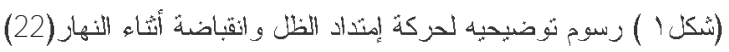
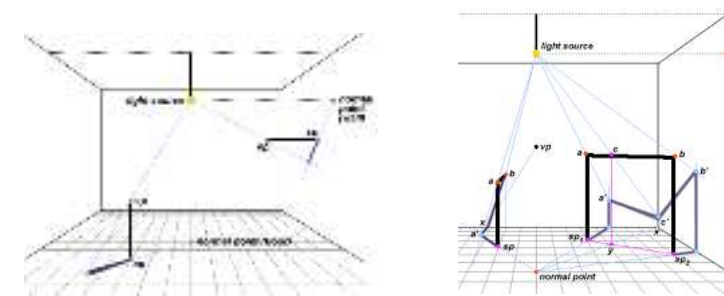

أ-و - أنواع الظل

تُصنّف الظلال حسب الضّوء:

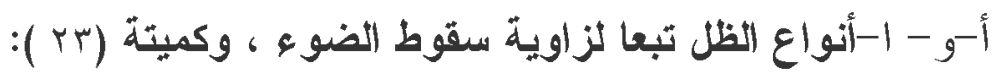

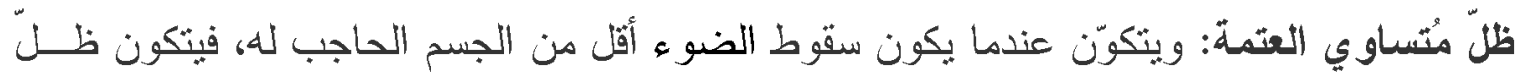

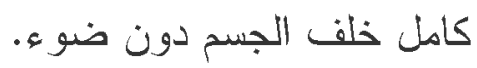

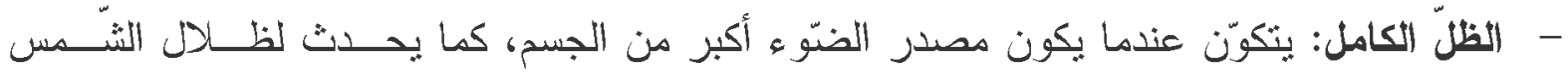

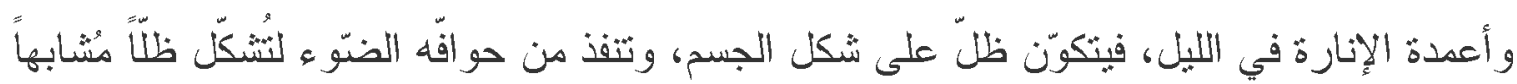

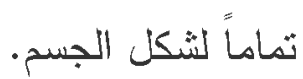

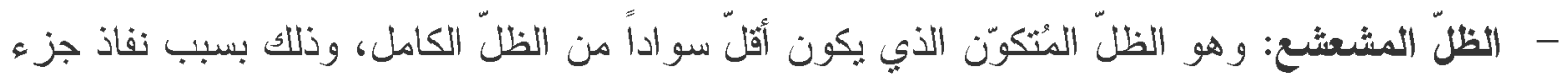
هن الضّو عن أطر اف الجسم أو يكون الجسم شُبه مُعتم.

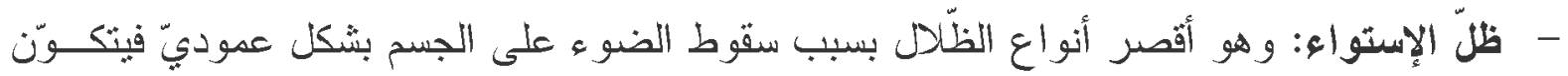
ظلّ قصبر جداً.

(AmeSea Database - ae - April- 2021- 0481) 
أ-و -ب- وفقاً للسطح أو لمجموعة السطوح - التى تستقبل الظل. نظرية الظلال و هي فرع من فروع الهندسة الوصفية، وتستخدم في تمثنيل ظلال الأجسام بالنسبة لمصدر

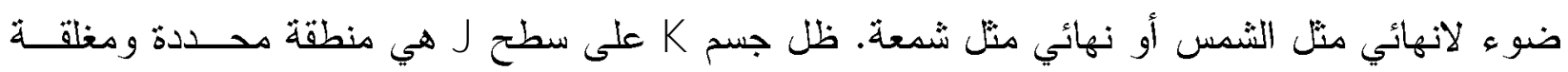

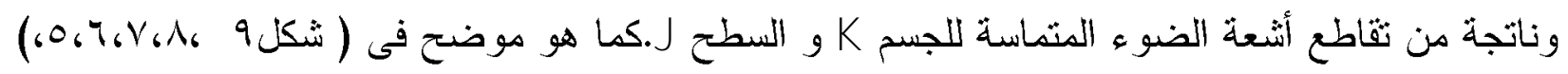

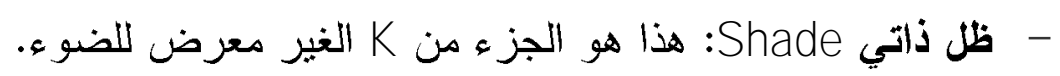
- ظل ساقط Shadow: هو إسقاط لحدود الظل الذاتي على الأسطح الدجاورة.

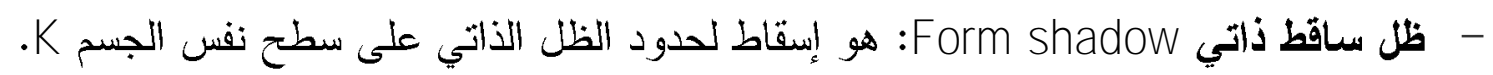
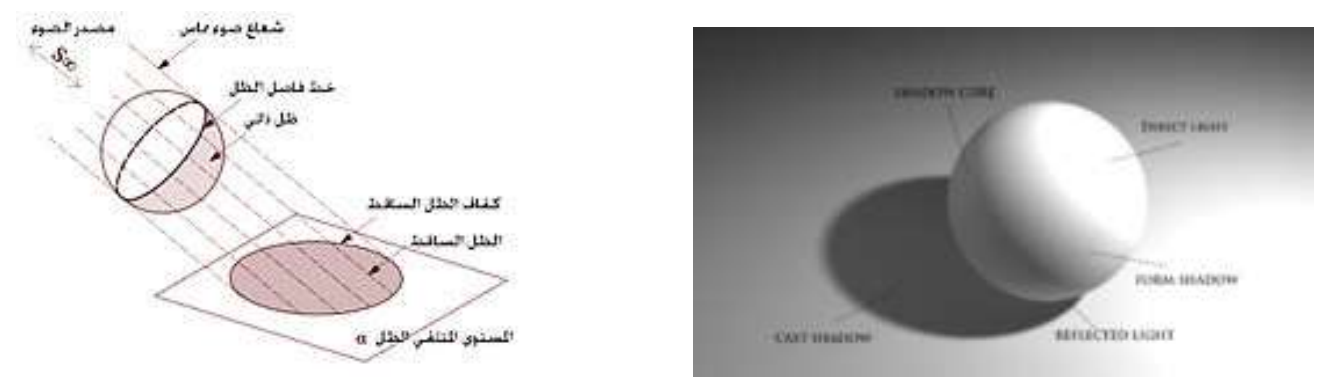

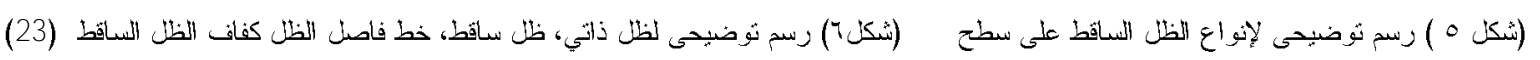
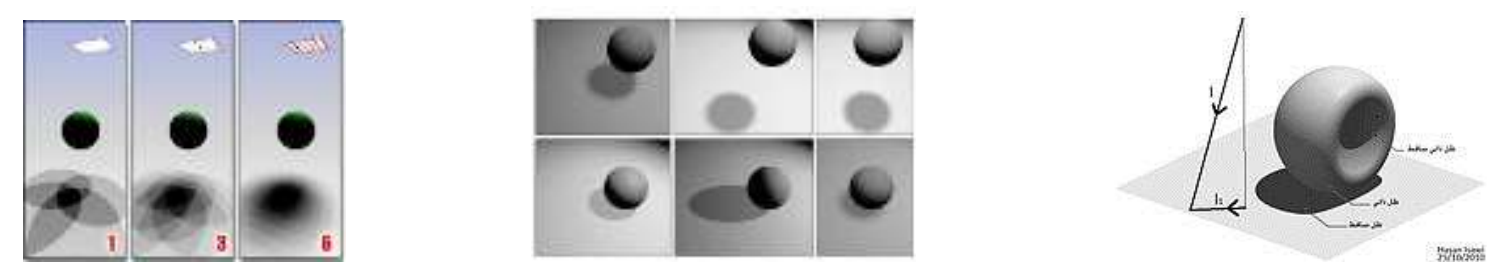

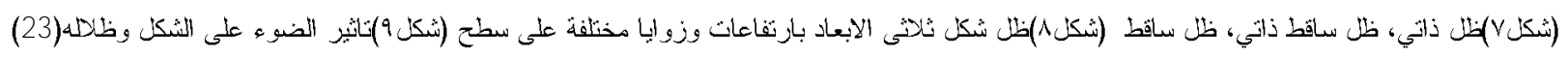
كفاف الظل للثكل ، " هو مجموعة من نقط ثقاطع أشعة الضو = الماسة لذلك الثكل مع المستوى المثلقي للظل. ولرسم الظلال من الضروري تحديد الخط فاصل الظل وهو الذي يثير إلى الخط الذي يفصل بين منطقة الظل ودنطقة الضوء لنكل ما. إسقاط الخط فاصل الظل على سطح، بحدد كفاف الظل الساقط على نفس السطح بمكن اعتبار الخط فاصل الظل كالكفاف الظاهر بالنسبة لمركز نظر مثطابق مــع مصــدر الضوء. الذي يمكن أن يكون نقطة لاتهائية منل الثمس، وفي هذه الحالة أشعة الضــوء تنكـون موازيــة لبعضها البعض، أو إنها ثتقارب، عندما يكون مصدر الضوء نقطة نهائية مثل المصباح. ومسـن الممكـن ثمييز الظل الذاتي السـاقط بظل الكيان الذي يقع على سطح نفس الكيان." (24) تشــمح الظـلال غالبــا. (AmeSea Database - ae - April- 2021- 0481) 
بإستكمال المعلومات ثيلاثية الأبعاد لنشكل ما، لأنها تعتبر رؤيا من مركـز إسـقاط آخـر، أبي أن هنـاك

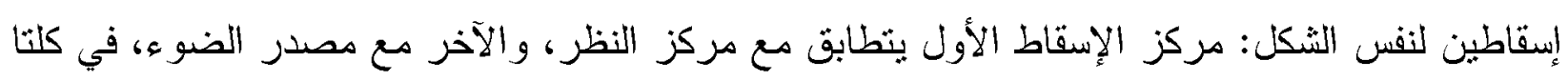

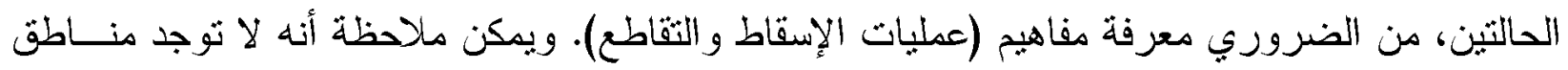

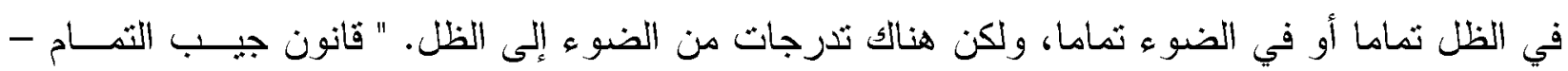

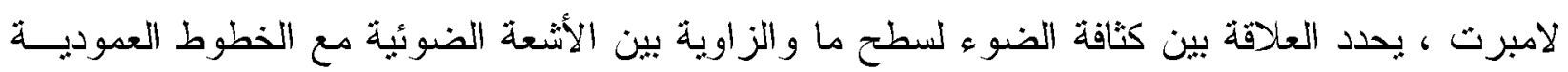

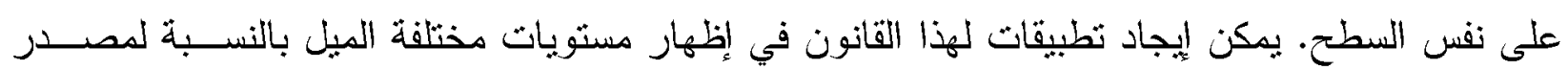

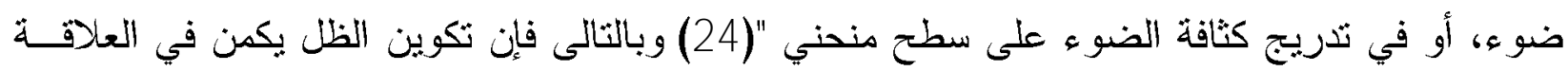

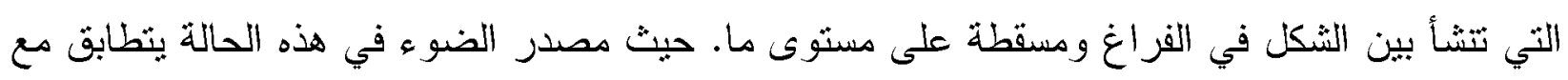

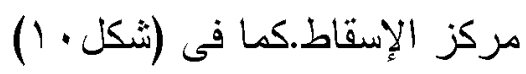

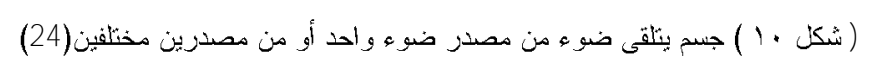

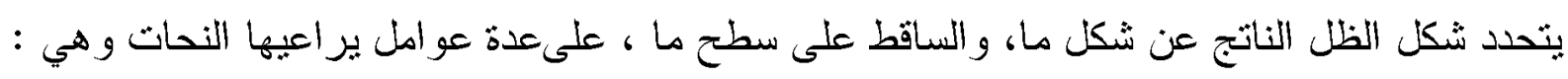
1- - 1- بيئة الثكل وحدوده الخارجية. r- طبيعة الشكل ـ شفافيتة ومدى صدادئة

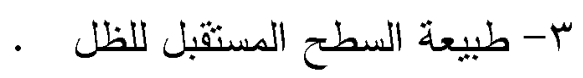
؟ - الز اوية الأفقية و العمودية للأنتعة الضوئية المثكلة للظل ه- شدة الضوء.

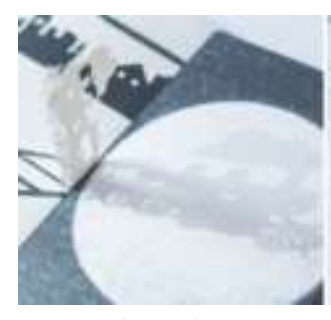

(1)

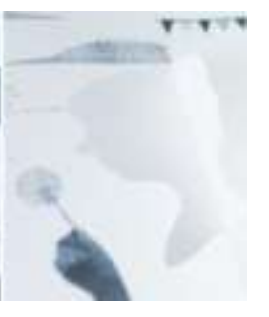

(1)

(1)

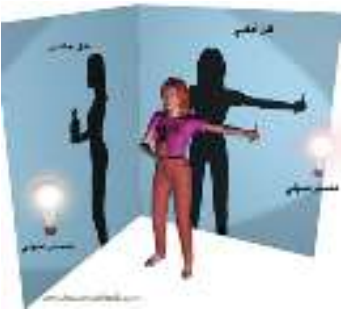

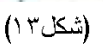

$$
\text { (- مدة الضوء. }
$$

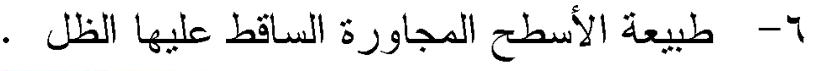

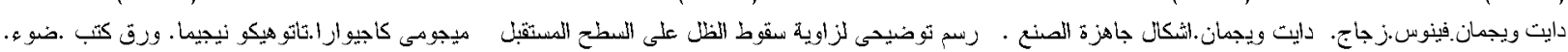

(广N)

(TV)

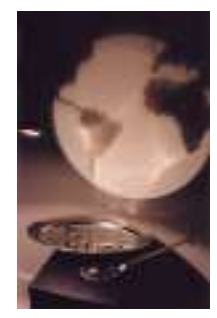

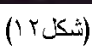

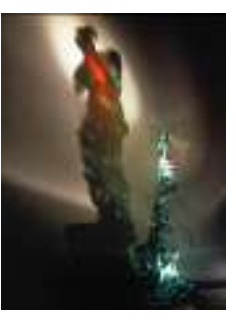

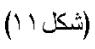
اليابان

(AmeSea Database - ae - April- 2021- 0481) 
يلاحظ أنه فى (شكل (1) نم بناء الثكل وتركيبه من مجموعة من الزجاجات ذات خامات شفافة ملونة وقد

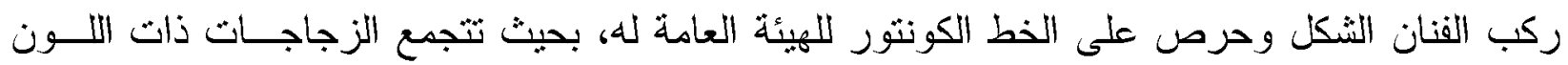
الو احد لتشكل حجما له وفى الأعلى بالمنتصف أضاف لونا أحمر من نفس خامة الزجاجات البلاســنيكية الثفافة لنعكس ظلالا لونيه لنكل فينوس مستفبدا من ثأثير الضوء على الشكل الشفاف ليضفى بعدا جمالبا

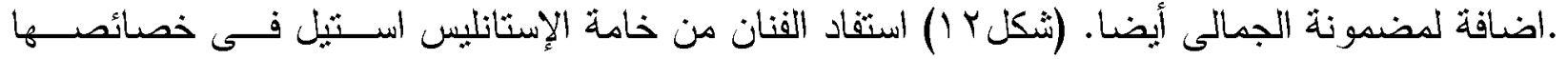
العاكسة للضوء لتعكسة على سطح شفاف مما يعمل على إضـاءثة ليحدث الثقابل بين ظل الثــكل المعـنت

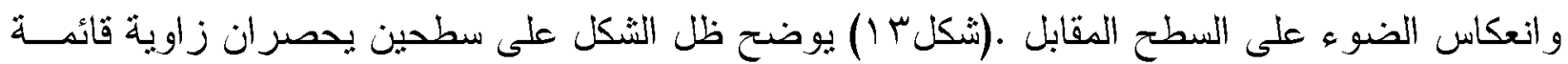

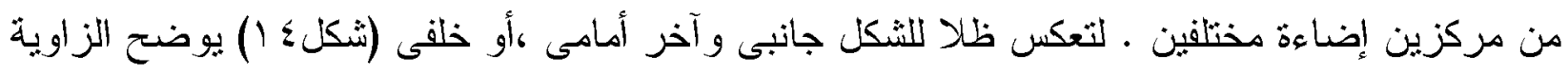
الأفقية العمودية للثكل ، وإسقاط ظله على سطح معثم كما يوضح شدة الإضاءة وثأثثير ها على إعثام الظل
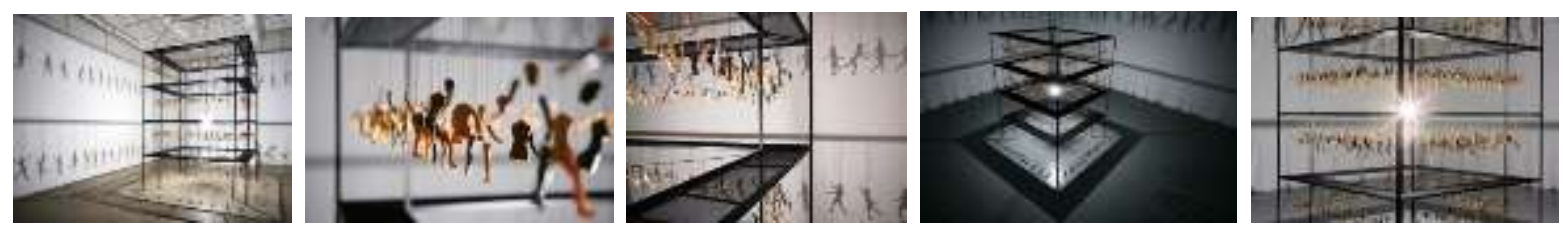

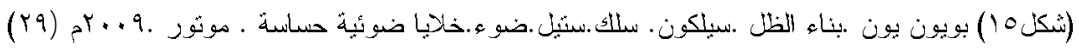

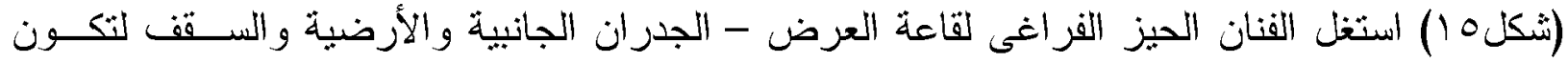

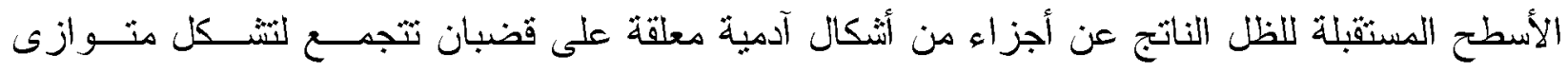
مستطيلات فى اتجاه قائم لأعلى يحصر ضوءا في المنتصف تثريبا ـ و على الرغم من أن الأشكال مجزئة

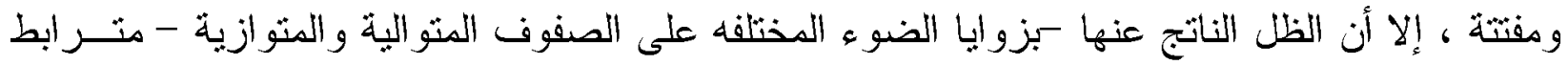
مشكلا هيئات آدمية فى حالة حركة ولعب لبشكل بها حياه ظلية،مدعما تلك الحركة الإيهامية حركة فعليـة بالموتور • ليوجد هذا الثقابل بالمعنى الدلالى للعمل الفنى ـ فبالرغم من التشتت و التفرق فى بناء الأشكال

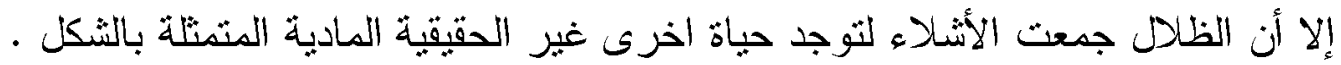

ب- الثكل: أصبح هناك العديد دن المتغيرات التي غيرت في صياغة الثكل وظلاله وبالتالي إلى قراءتة وفق متغيرات الدلالة التي أصبحت من خلالها ينتظم الثنكل الجمالي في العمل النحتى فيعرفه جيـروم : "

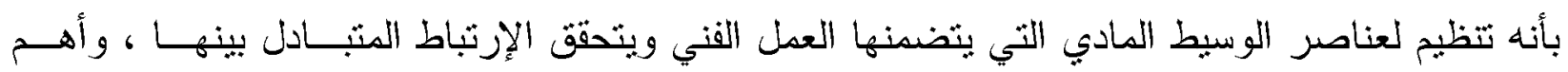

(AmeSea Database - ae - April- 2021- 0481) 


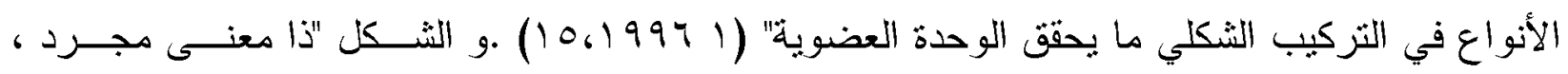

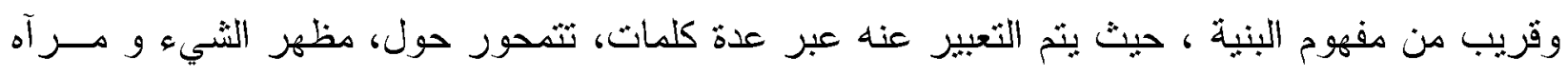

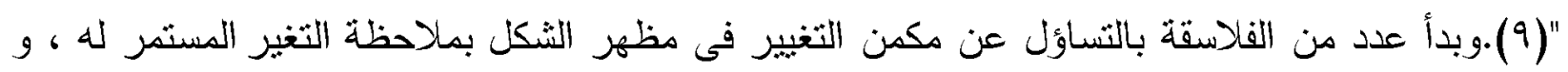

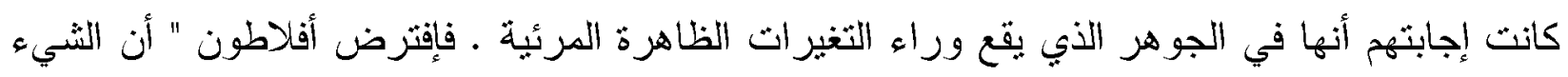

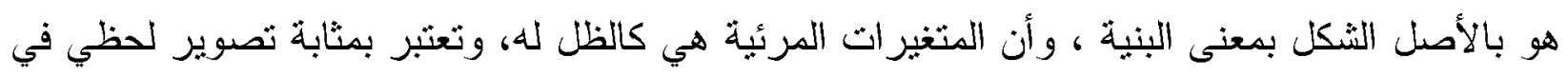

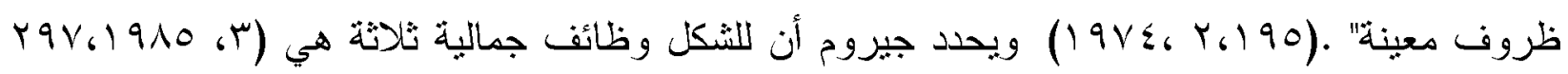

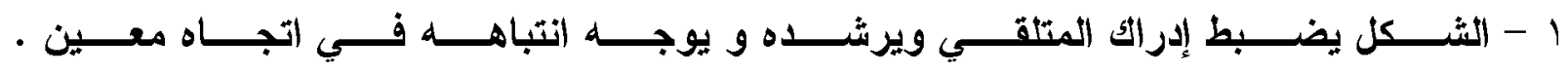
r- الثكل بأكمله يرتب عناصر العمل الفني على نحو من شأنه إبراز قيمتة الحسية والتعبيرية . r- للثنكل أهمية بحيث لا تكون للمضمون قيمة باونه فهو الأي يدل عليه.

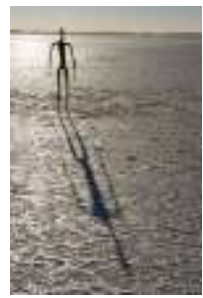

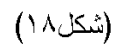

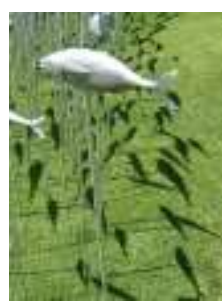

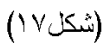

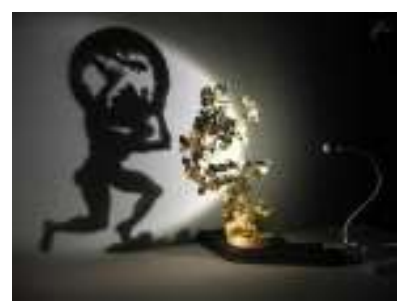

(شكن (17)

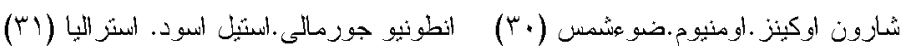

دايت وجمان نحاس .ضوء (TV)

(شكل، 1) عبارة عن حجم فراغى يتكون من مجموعة من الأشكال الدائرية نسندعى تصور ا ذهنيا لشكل

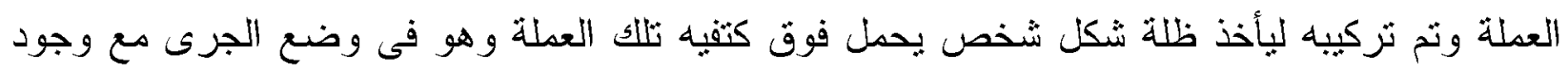

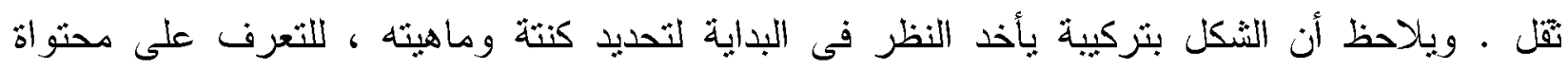

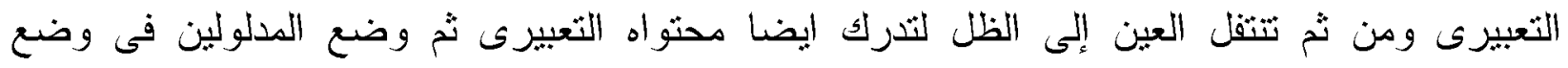
المقارنة لإيجاد المفهوم الكلى للعلاقة بين الثكل ككيان ثائم بذانة ـ والظل ككيان آخر بينهم علاقة

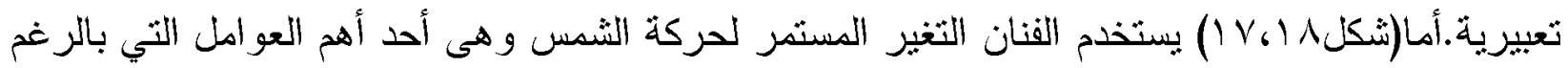

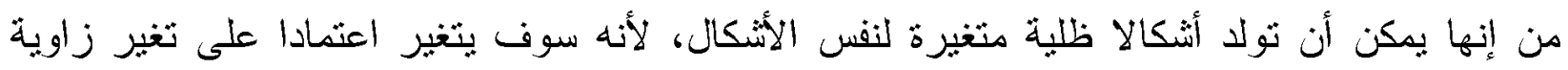

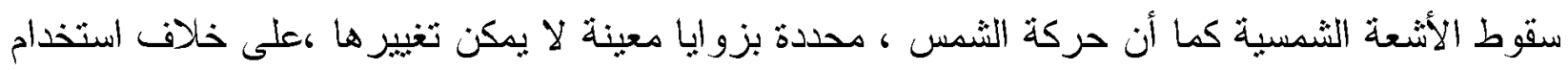

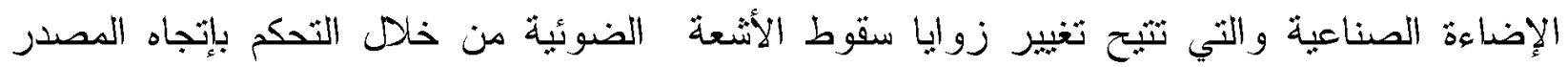

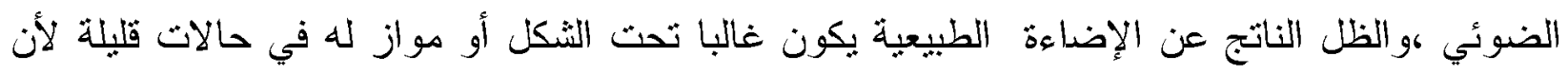

(AmeSea Database - ae - April- 2021- 0481) 
الثمس تككن دائما أعلاه ،فقى (تشكل V) استخدم الفنان ظلالا متغيرة لسرب الأسماك المثبتة على قضبان

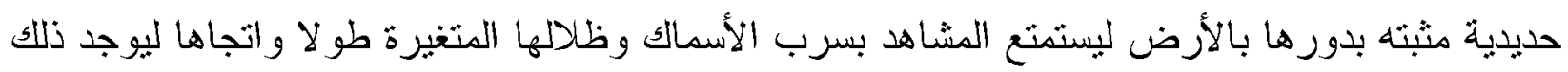

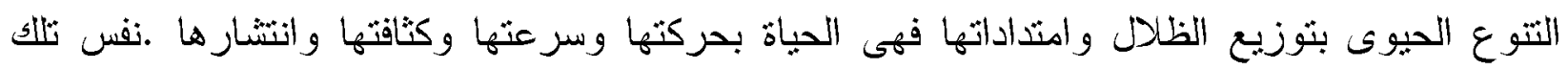

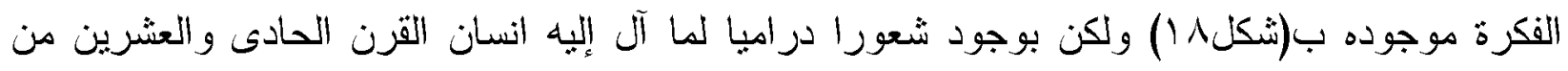
وحده وشتثات ونتشوه .

ثانيا : المستوى الجمالى • إن ثأثثر الثكل و الظل و الضوء على بعضهم البعض من حيث الإدر الك للقـبح

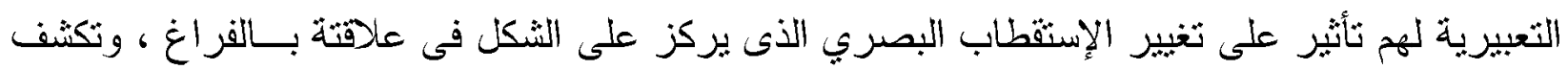

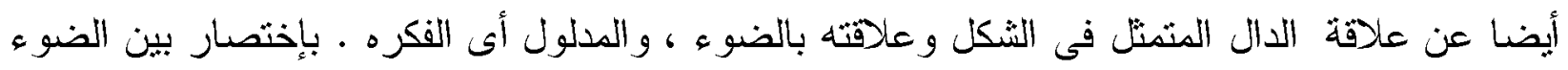

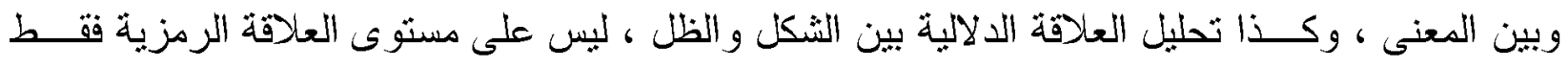

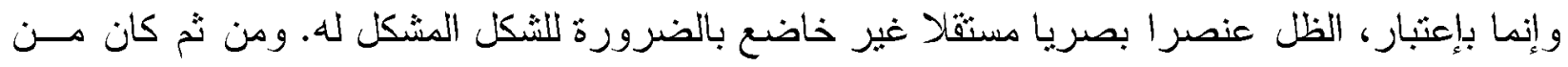
الداعى تتاول مفهوم الدلالة فى العمل الفنى.

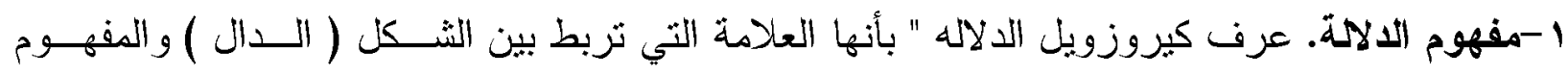
الذهني أو المعنى (المدلول) وتعتمد هذه الر ابطة على وجود ( علامة ) تكسب الدال و المدلول صفة تحيلها

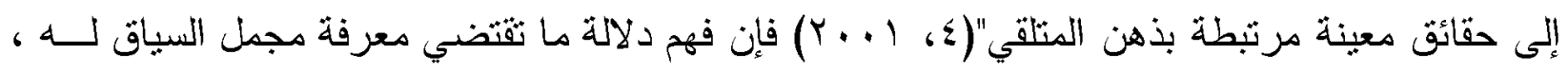

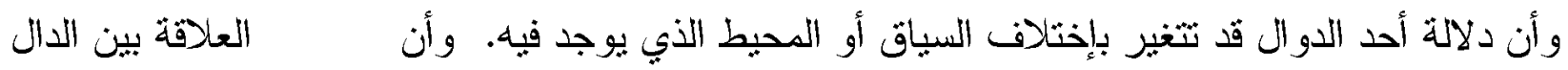

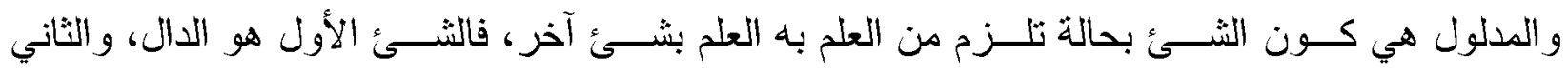

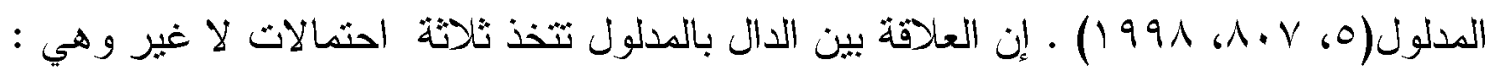
أ-المطابقة:

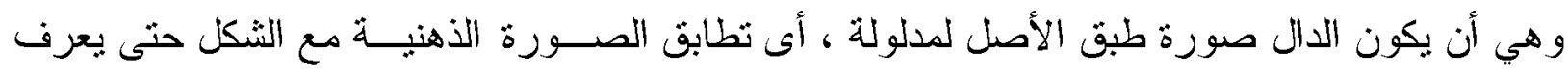

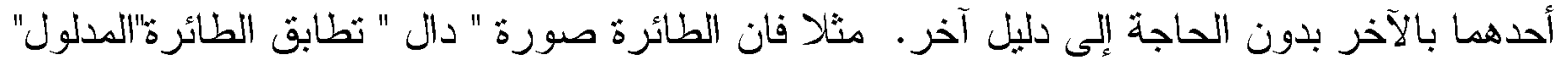

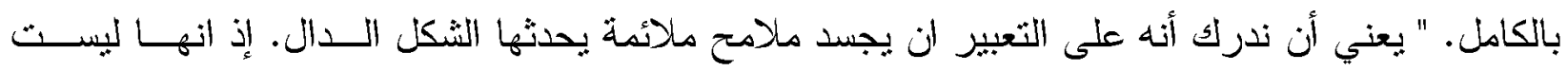

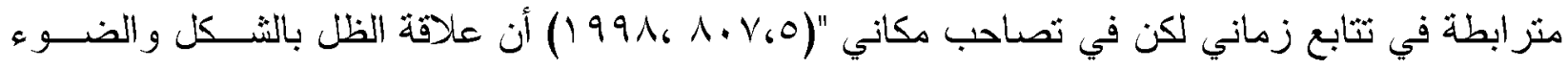

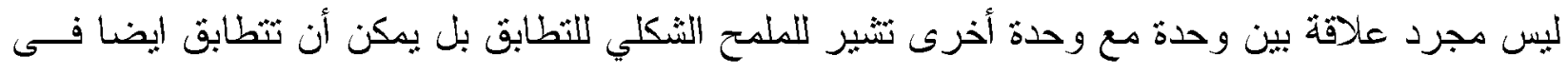

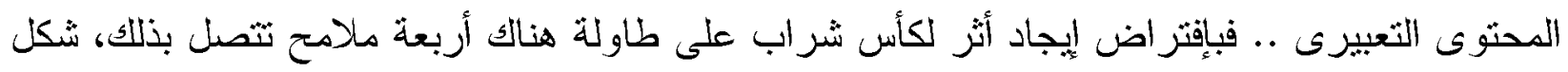

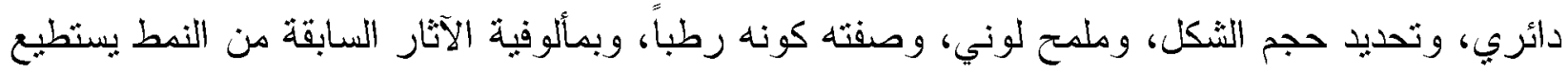

(AmeSea Database - ae - April- 2021- 0481) 


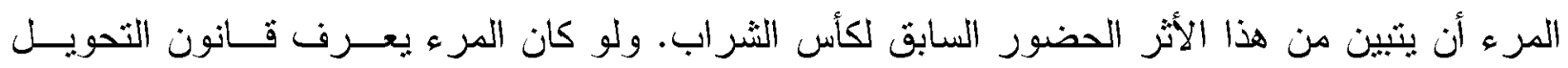

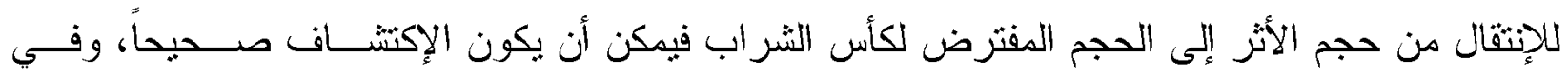

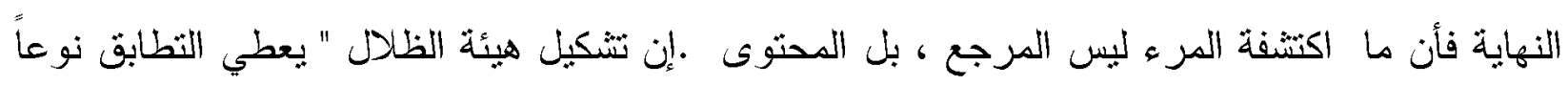

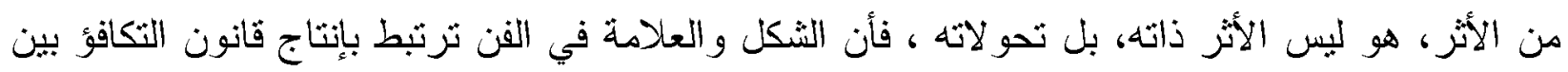

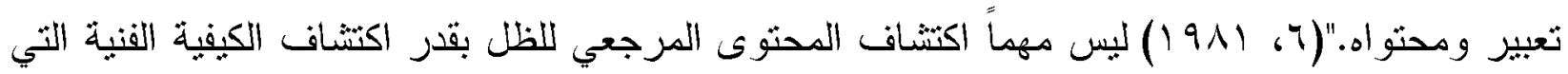

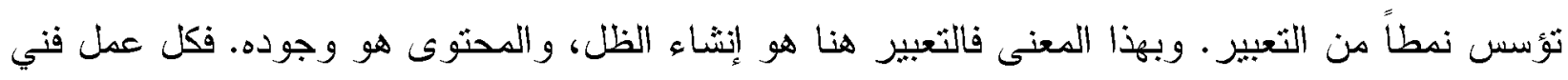
فى رأي لانجر" ليس له عناصر وهمية واخرى فعلية ممزوجة فيه، فالمواد فعلية لكن عناصر الفن دائمـاً.

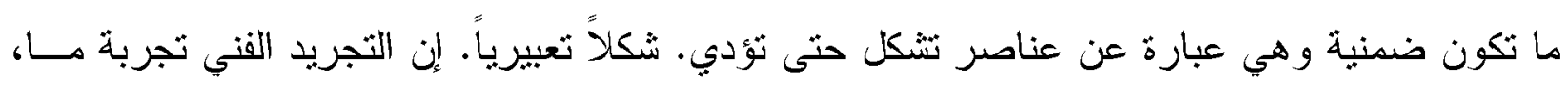

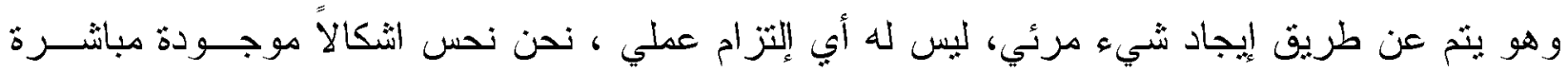

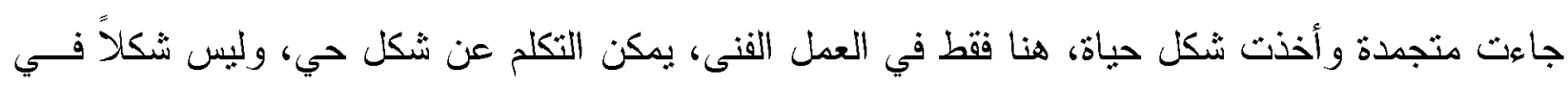

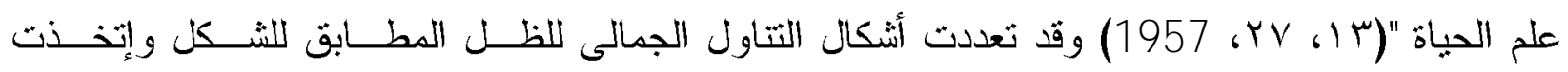
الصباغات الإنشائية النالية :

أ- 1 -انثاء الظل لإيجاد محتوى تعبيرى مطابق للمحتوى الثكلى كخبرة جمالية معاثةة :

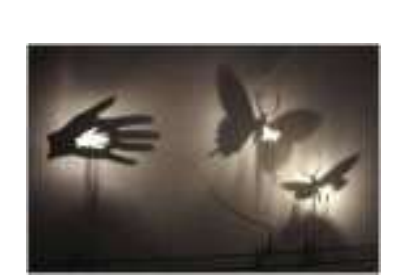

(ش)

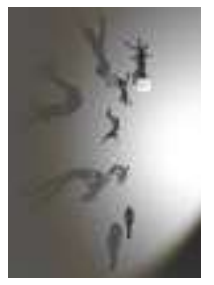

(شكل) (r)

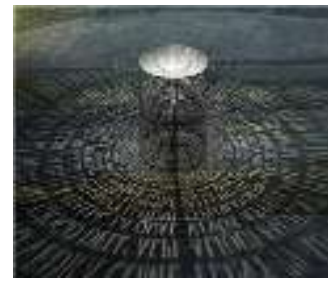

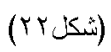

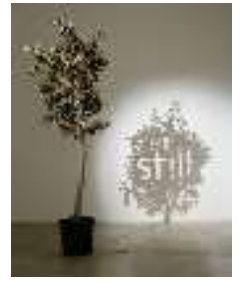

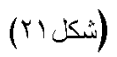

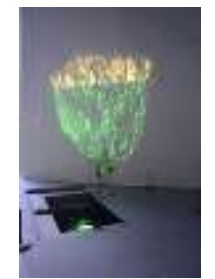

(شكل . ( ) )

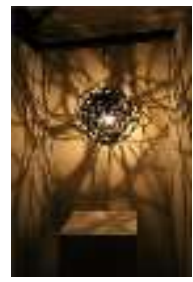

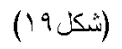

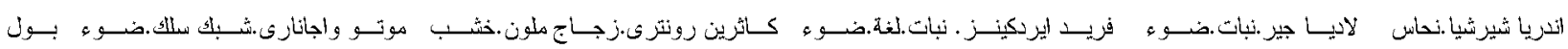

(37)

(14)

(ro)

$(r \xi)$

(rr)

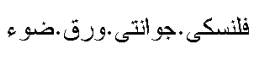

(rY)

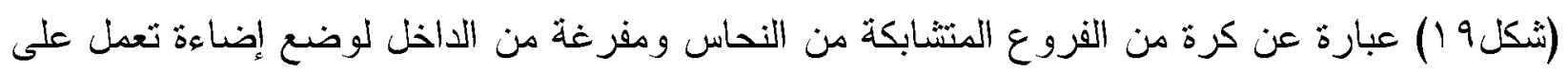

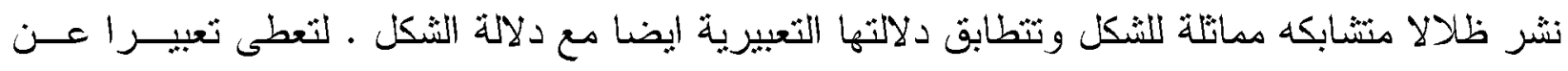

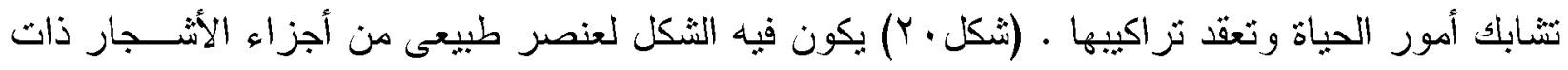

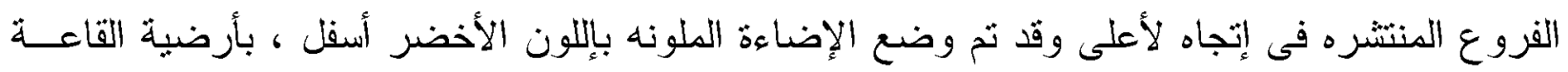

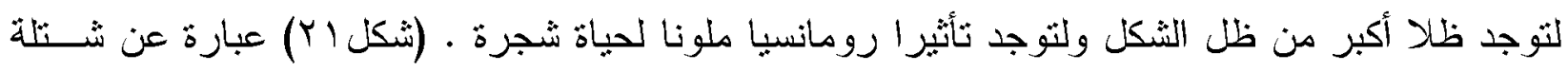

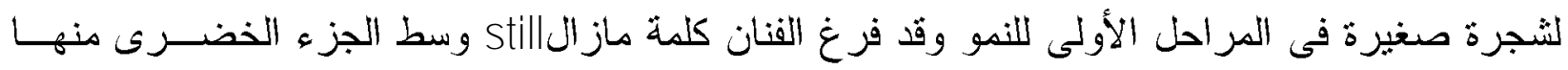
(AmeSea Database - ae - April- 2021- 0481) 


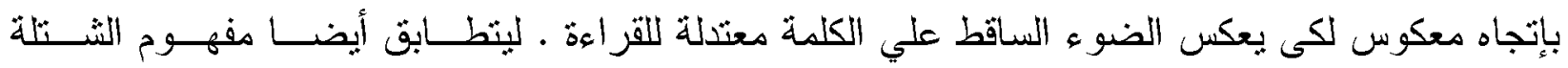

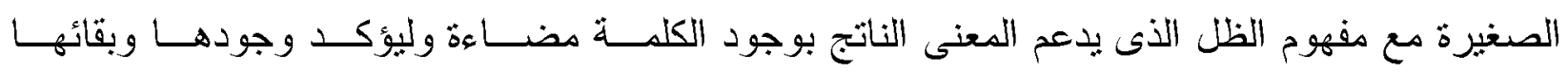

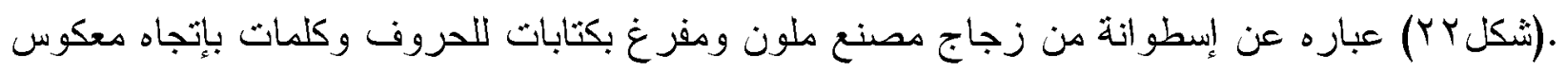

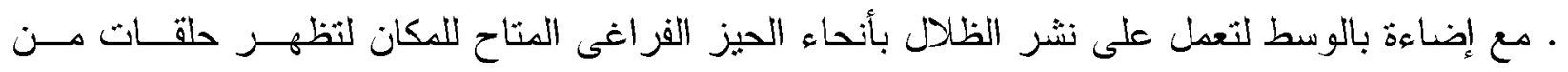

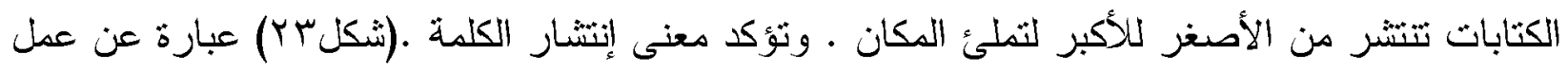

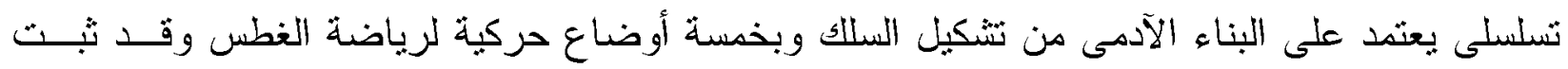

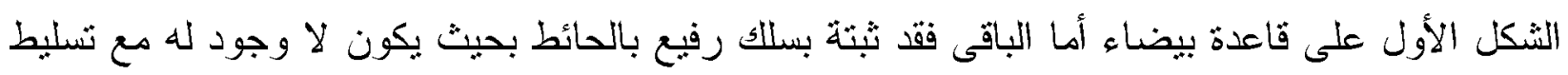

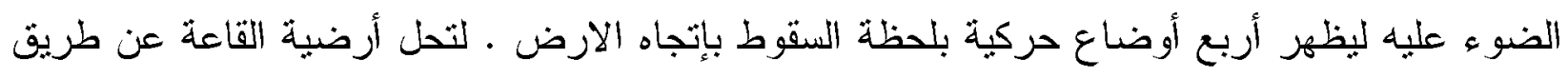

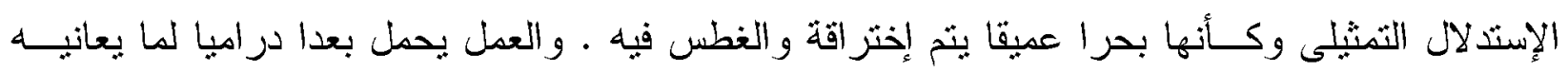

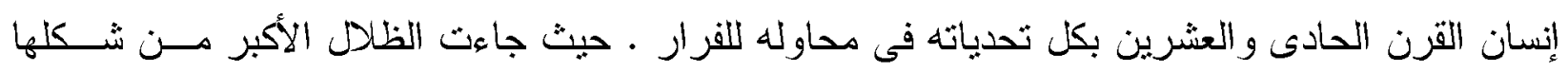

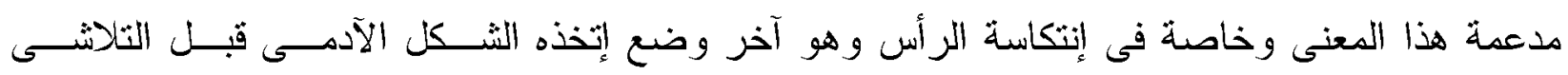

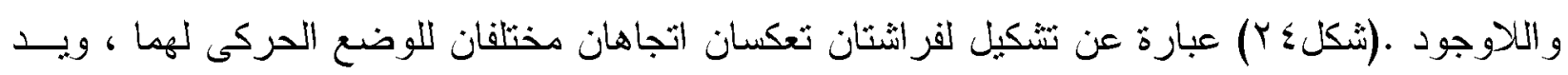

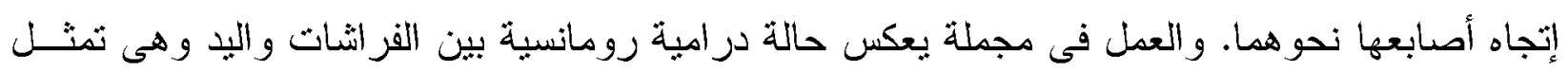

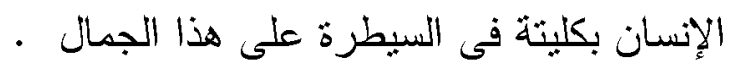

أ-r-إنثاء ظل متحرك لإيجاد محتوى تعبيرى مطابق لتعميق المحتوى التعبيرى للثــكل. أهم ما يميز

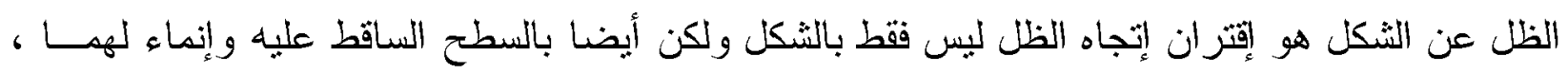

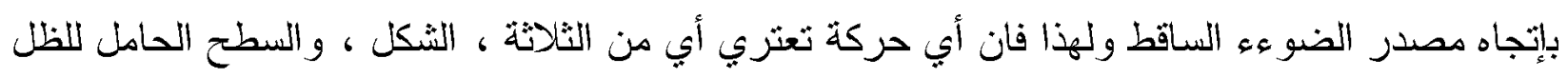

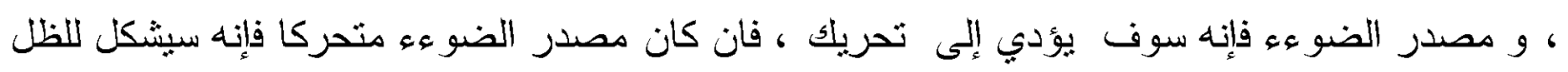

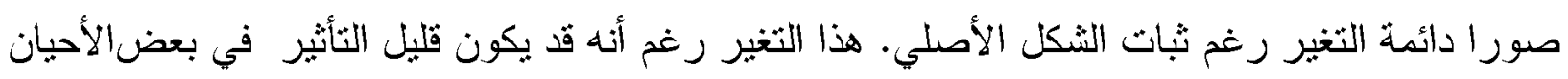

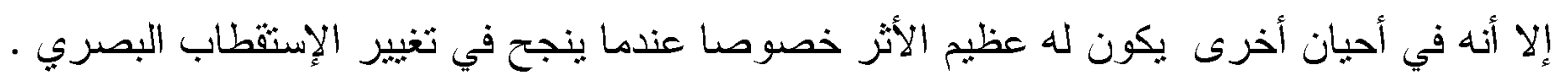

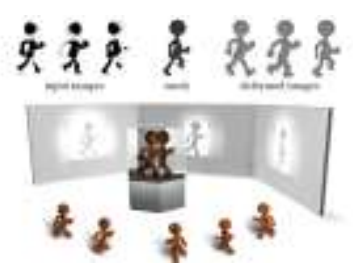

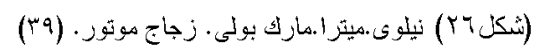

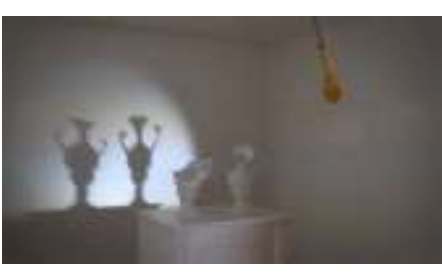

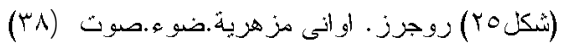

(AmeSea Database - ae - April- 2021- 0481) 


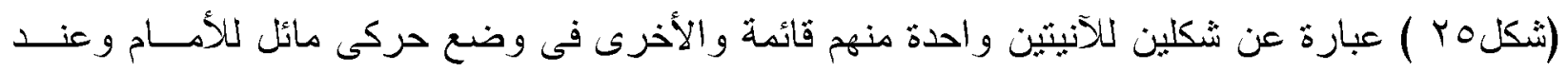

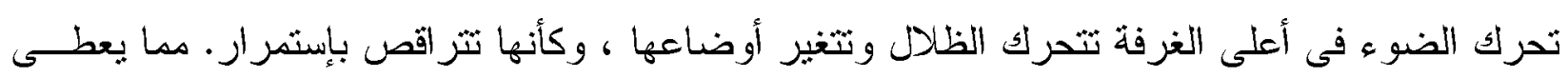

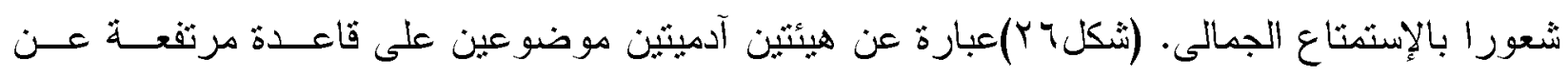

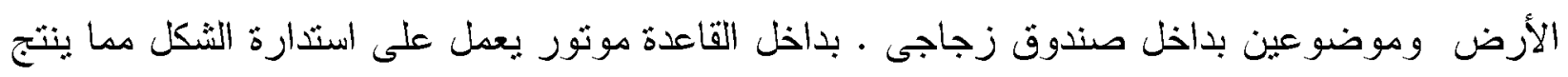

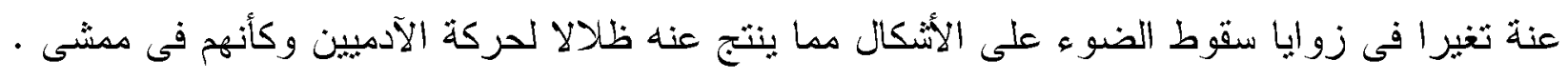

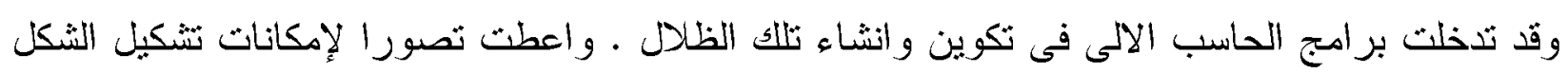
ثلاثى الأبعاد. أ-r-انشاء الظل المطابق كموقف تفاعلى . العلاقة بين المتلقى وبين الأعمال الفنية ليست علاقة واحدة

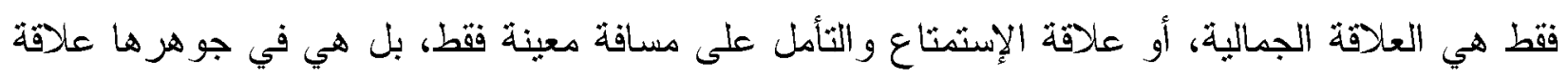
موقفية تعثد على طبيعة التفاعل بينه وبين العمل الفني في موقف معين ،وكلما كان العمل الفني قادراً على النشاط و التأثير في مواقف متعددة، تعددت تفسير اتة وتأويلاتة ومستوياتة، و وأصبح أكثر ثراء.

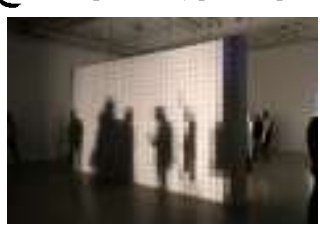

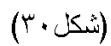

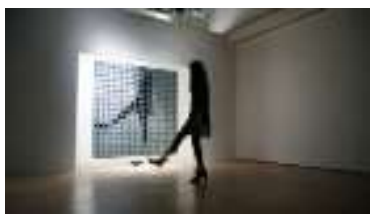

(

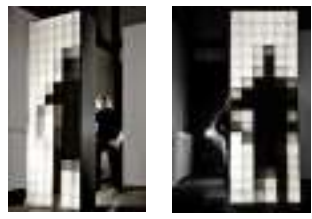

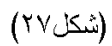

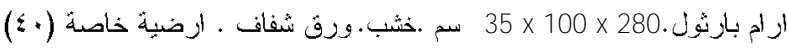

ويلاحظ من خلال تلك الأعمال القائمة على تتكيل الظل ددى التفاعل بين المتلقى وبين الجدار المـزودة

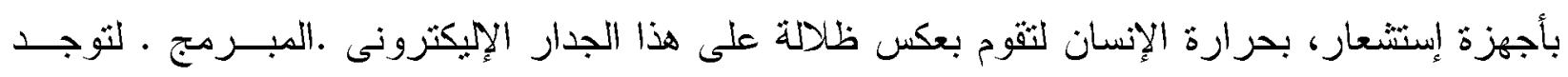

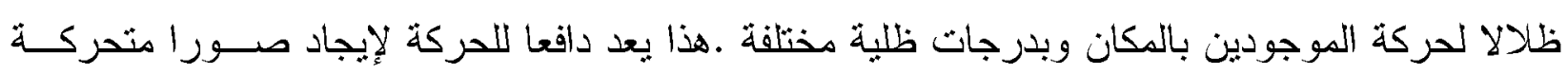

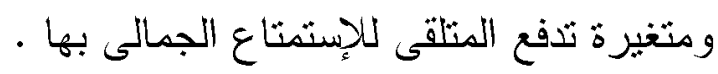

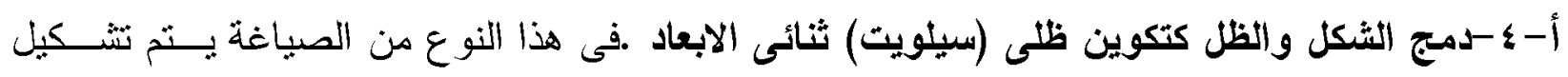

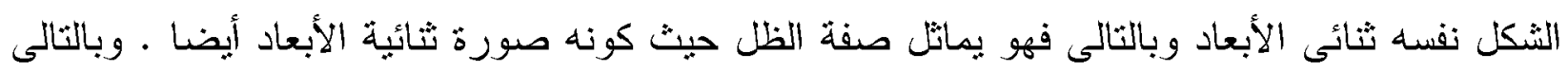

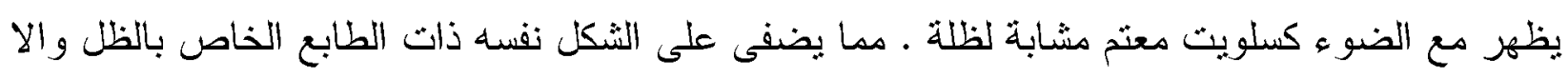
و هو الغموض والضبايية وفى بعض الاحيان الحزن .ويعد عامل الحذف للبعد الثالث نوعا من التعبير.

(AmeSea Database - ae - April- 2021- 0481) 


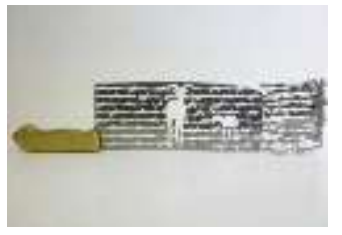

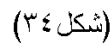

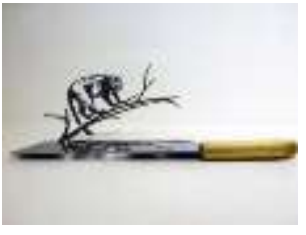

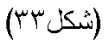

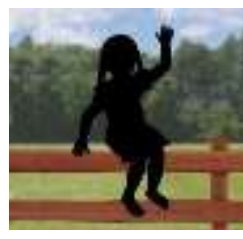

(ش) (ش)

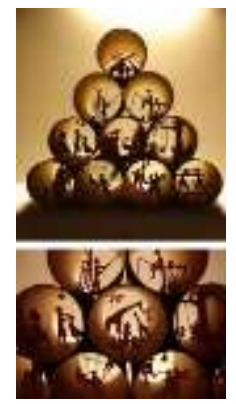

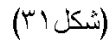

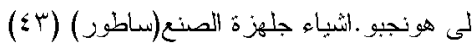

وود باتزرن خشب.ورف اسود(r)

أسطو انثة ورق تو اليت.ورق. ضوء(1)

(شكل آس) عبارة عن مجموعة اسطو انات بالورق المقوى وتم التشكيل بداخلها صورا مختلفة من الحياه البومبة عن طريق لصق الخط المحدد للشكل ( الخط المحيط -المحد) لمجموعة من الأشكال الورقية ثثائبة الأبعاد ـ على امتداد عمق الإسطو انه بشكل به نوع من النز اكب ـ لتعكس عند سقوط الضوء عليها

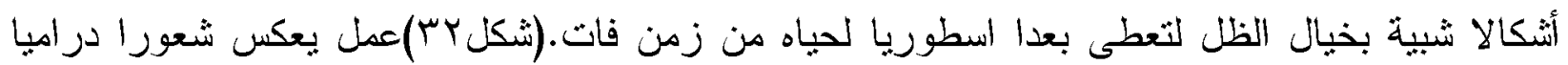
لوجود الطفولة بالمتنزهات وما يصاحبه من معانى الفطرة والثلقائية والحباة البريئة .بوجود شكلا مشابها

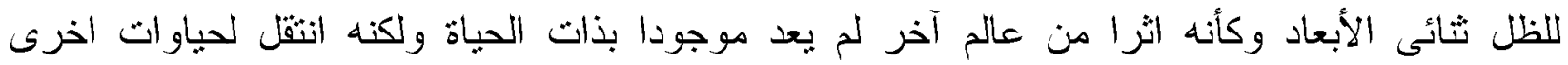

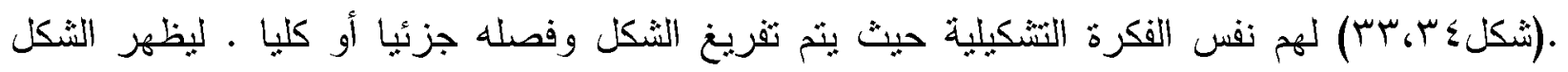

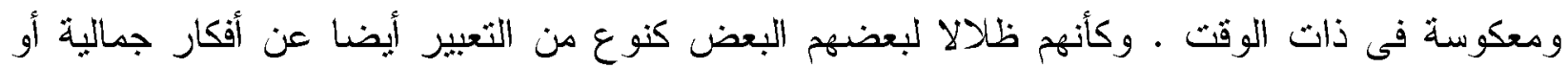

ب-المغايرة: ينضنمن أن الدال يغاير المدلول في بعض الأتشياءه ويثـــــابها في بعضها، وهو الإختلاف

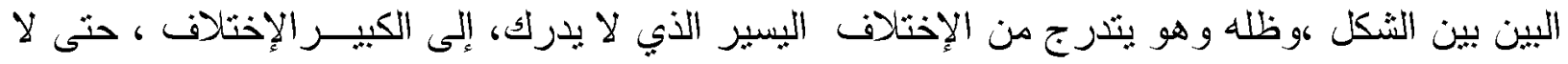
يعرف أحدهما بالآخر ،إلا بوجود بينيثـة ـ مثثلا ، صورة مقطع جناح الطائرة "دال" قد يدل على الطائرة

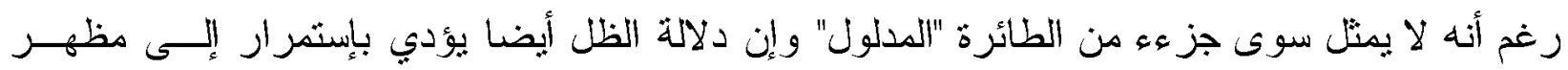

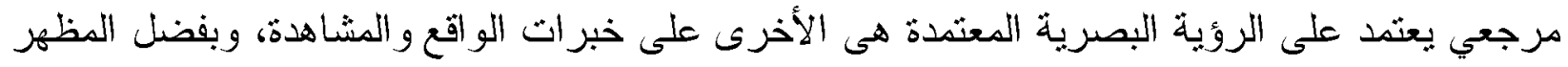

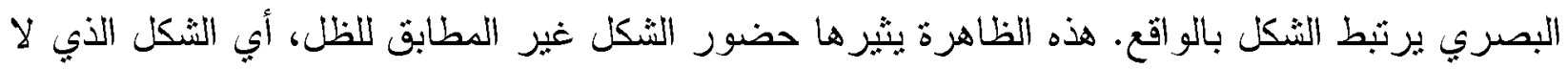

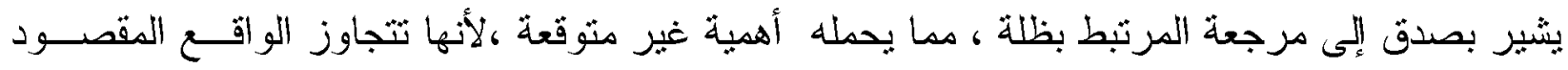

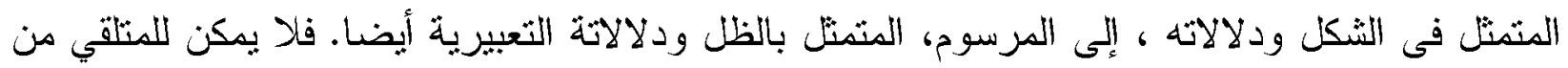

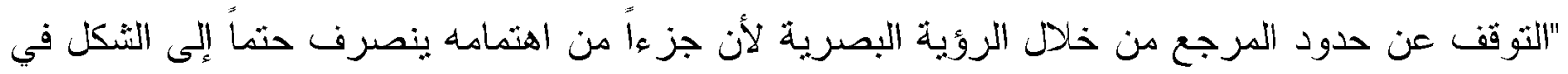

(AmeSea Database - ae - April- 2021- 0481) 


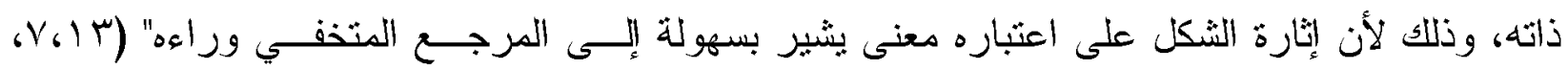

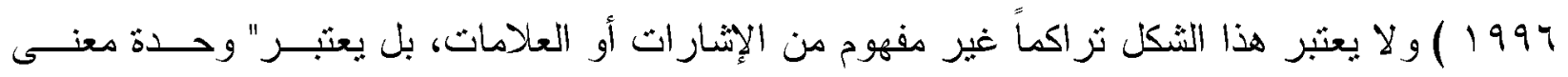

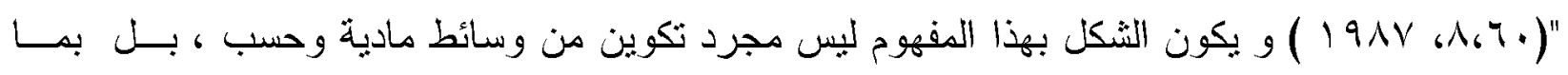

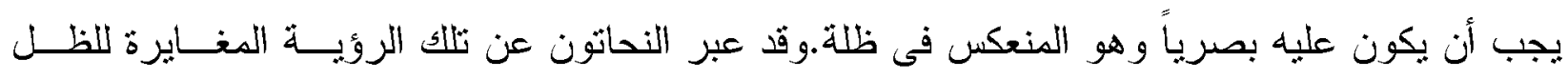
و اتخذت عدة صياغات منها :

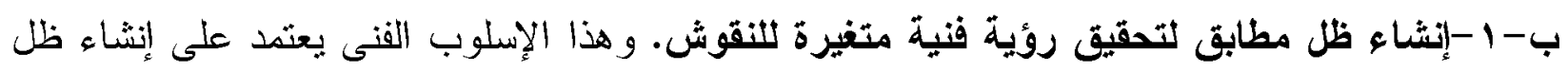

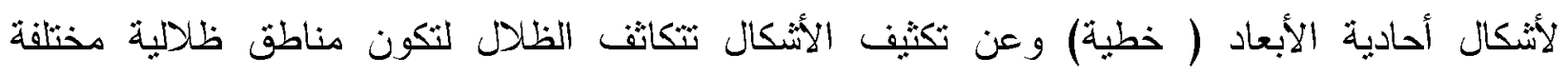

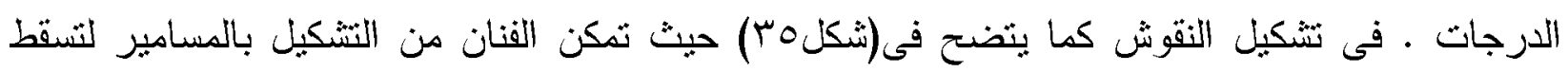

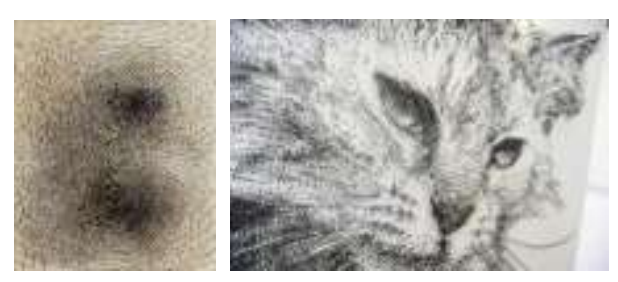

ظلالا مطابقة

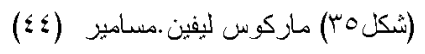

لشكلها فقط ـ و عن طريق عملية التركيب بالتكاثف و التخلخل لتسقيط ظلالا متدرجة التونات لإيجاد ظلالا

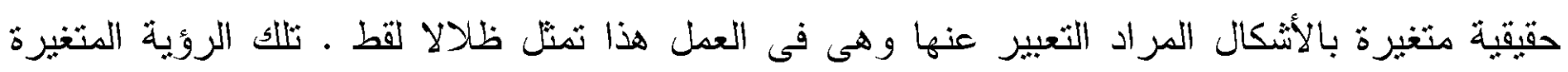

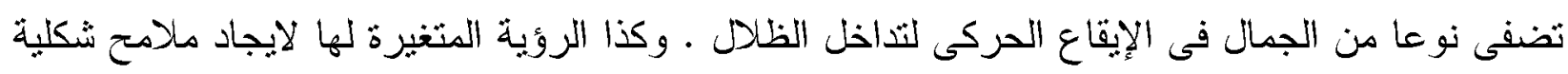

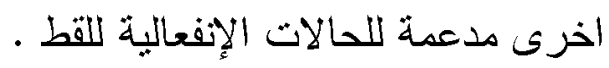
ب-ץ- إنثاعالظل المغاير للثكل كإستدلال تمثيلى لثكل آخر .الظل المستعار • بعتبرعملية تكوين ظله

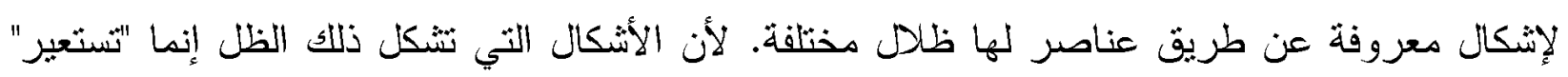

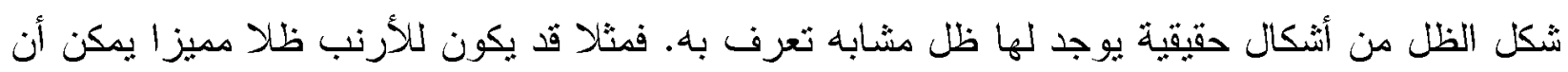

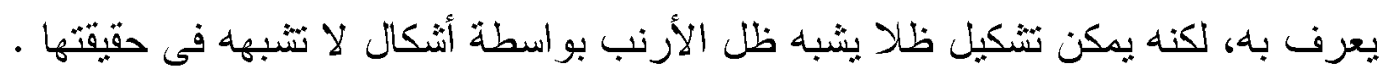

(AmeSea Database - ae - April- 2021- 0481) 


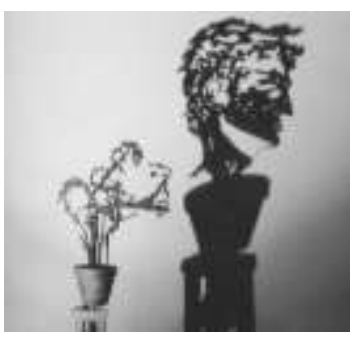

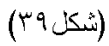

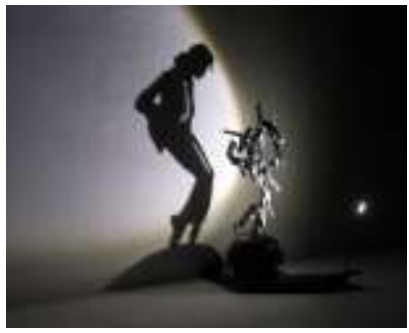

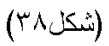

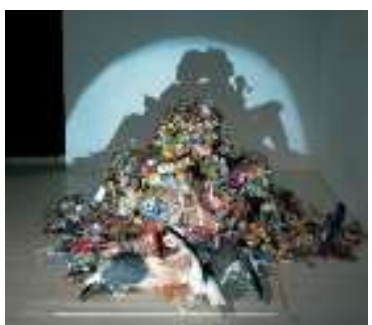

(

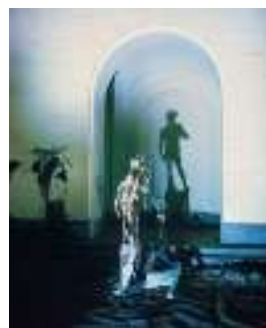

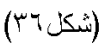

(TV) (IV)

بو افى خشب.طيور محنطة (TV)

دايت ويجمان .ضو و.مستهكات. (TV) ثيم نويل. علب فار غة (S)

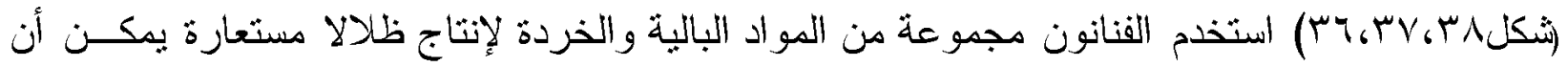

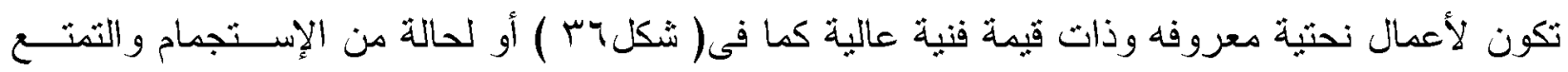
بالهدوء كما في (شكل Vاr) أو قد يكون لشخصيات معروفة تعد من علامات الفن العالمى كظل الفنان مايكل

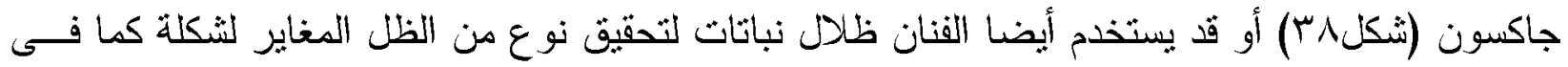

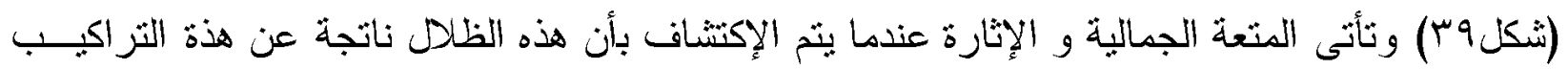

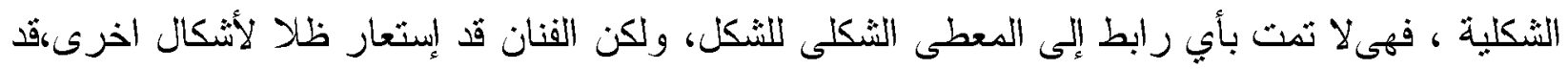

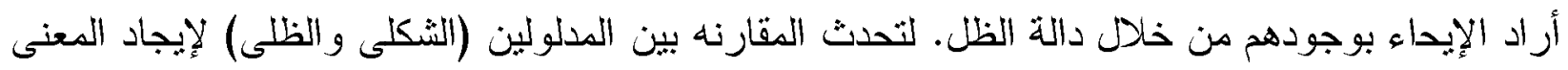

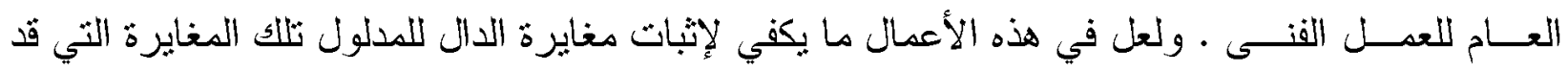
تتعدى المغايرة إلى حدودالمفارقة.

-الصياغات التثكيلية للإستعارة الظلية.بثم نكوين الظل فى ثلك الصياغات عن طريق صور للظل المطلوب المنكون من بعدين ، ذلك الذى بسبب وجود الثكل الثلاثى الأبعاد،أى بثم بطريقة عكسية فعن طريق "استخدام بر امج الحاسب الآلى، يثم تحديد الظل المرغوب فيه من خلال توفير صور رثمبه/ثنائية

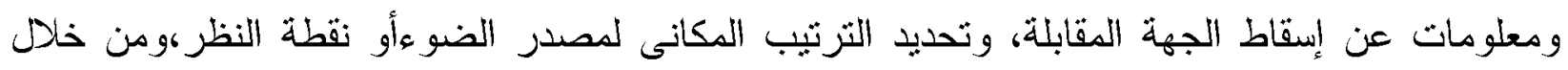
تلك المدخلات يثم عمليات تحسين هندسى يحسب حجم الظلال المطلوبة والتى من خلالها يثم الحصول على الثنكل المنحوت "( 15)إن حجم أو كتلة الثنكل النهائى يثعدل من خلال مجموعة من أدوات التعديل التفاعلية التى تحثرم القيود المعقدة للظل. ويثم بناء الثُكل عن طريق الآتى:

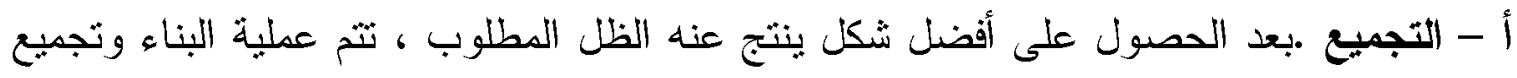

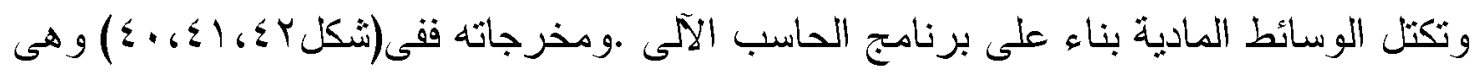




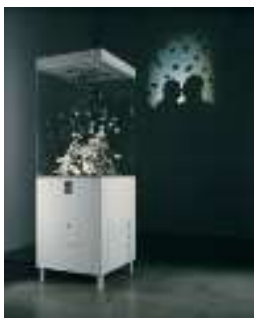

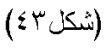

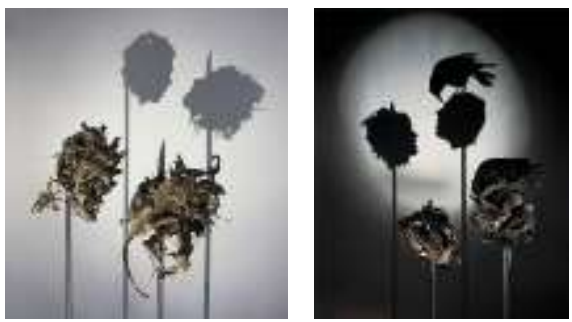

(ה) (A)
(ش) (ش) (

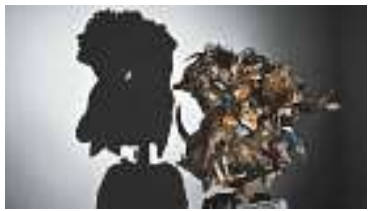

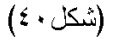

ثيم نوبل.سو ويبستز

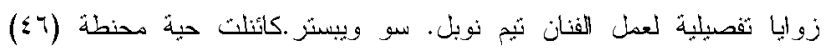

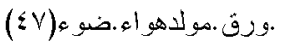

أعمال يثت فيها تجميع عدد من الكائنات الحية المحنطة لنتكل كتلنان مثبتثان على قضيبين قائمين ومثبتان

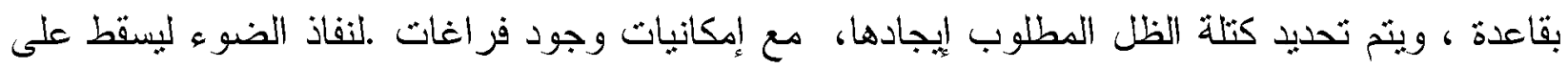

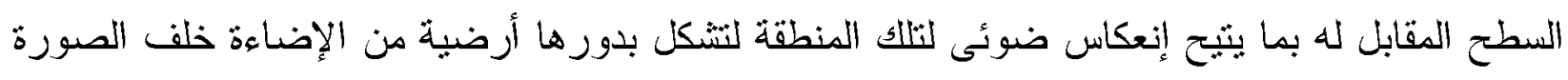

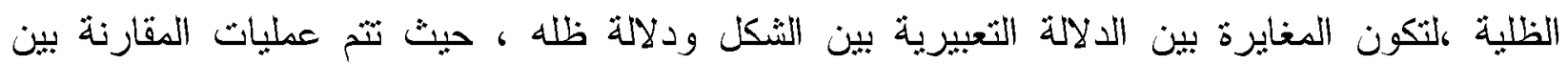

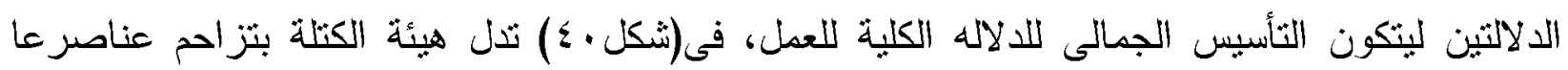
وتعددها وتداخلها لدرجة يصعب معها إدر الك ماهيثها، على ما نعكسة الحياه من التعقد و هذا في مقابل حياه

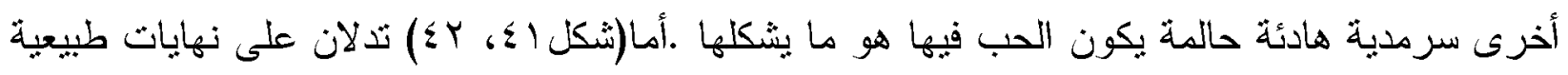

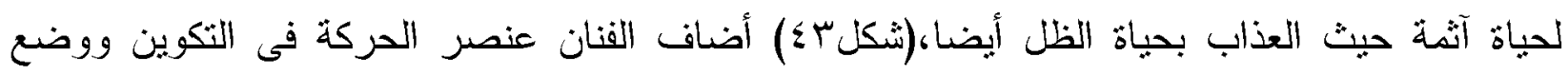

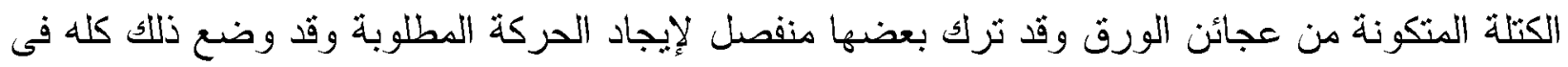

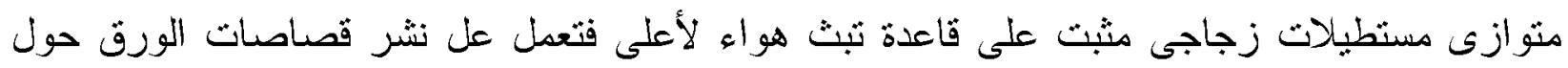
الكتلة الورقية لتوجد حالة من الرومانسية ذو طابع خيالى .

ب- التركيب .إذا كان الفنان يشكل الظل كعلاقة بين شكل وأرضية ثنائية الأبعاد أو علاقة فر اغية بالنسبة للنككل ثلاتى الأبعاد ،فإنه يلجأ إلى ثركيب الوسائط المادية بطريقة تعكس ظلانلا محكمة الرسم ، أما الثنكل

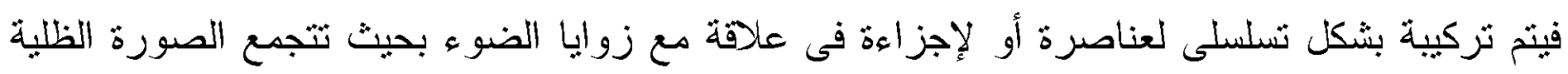

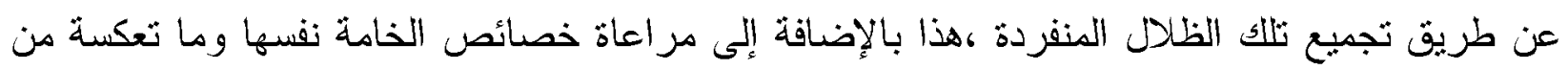
خصائص بصرية فى علاقتها بالضوء .

(AmeSea Database - ae - April- 2021- 0481) 


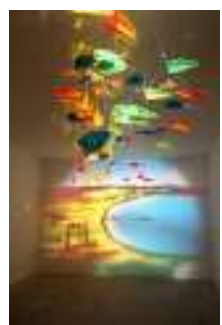

$($ (i)

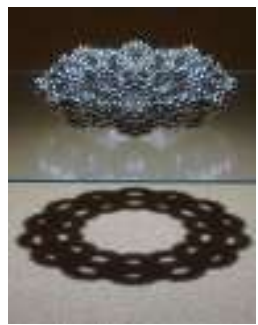

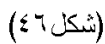

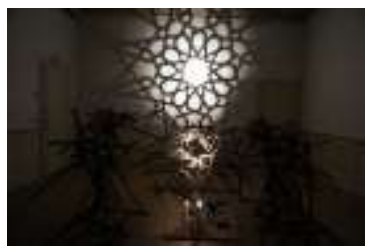

(شكل)

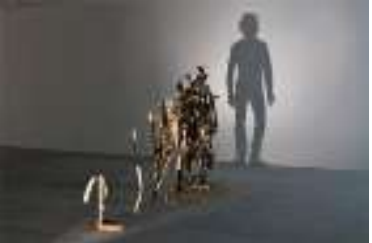

(ش)

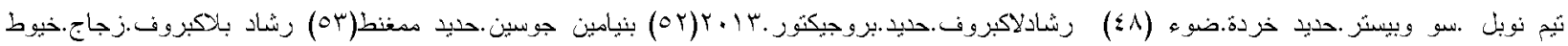
نايلون(O)

(شكلى §) يلاحظ نركيب الثكل من الحديد الخردة على مستوى أفقى ثركب عناصرة بتنابع بحيث نوجد شكلا تسلسليا مثتابعا لتر اكيب من الحديد بحيث ثتجمع الظلال على السطح المقابل لظل إنسان فى وضع الوقوف ـ(ثكلهء) ثركيب من الحديد الخردة مكون من ثنالث ثكوينات مكملة لبعظهم فى الحيز الفراغى للمكان ، ليكون ظلهم مع زاوية الضوء شكلا لنجمة إسلامية .وتأنى المغايرة بعدم التوقع بخروج نظاما محكما من اللغنظام الموحى به الشكل.(تُكل جء)تكوين من كرات عاكسة ممغنطة لتشكل حجما مفرغا موضوعا على حامل زجاجى ليشكل درجات لظلال ما بين الامع والمعنم عند إنكسار وانعكاس الضوء عليه.(ثكل Vミ) علق الفنان أجزاء الشكل وعناصرة الملونة والثفافة أعلى قاعة العرض،لتعكس ظلا ملونا يتم تجميع إنكسار اث الضوء على السطح المستقبل له ليشكل به لوحة لشاطى ضوئيا .

ج-الترتيب (التنظيم) المتسلسل.وفيه يثم تنظيم ونرثيب الوسائط المادية بنظام محدد فى علاقة مع

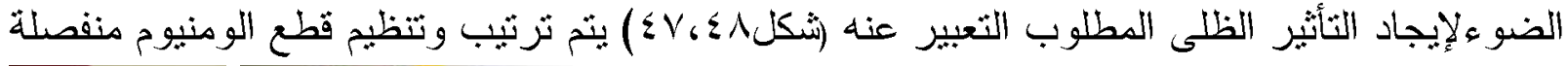

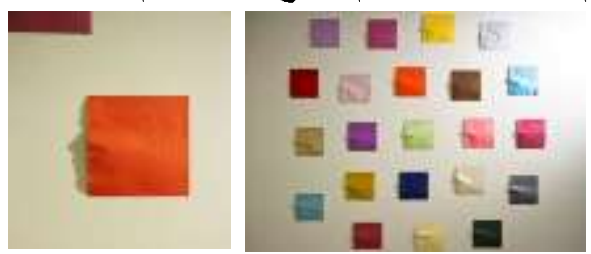

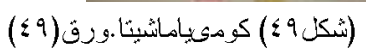

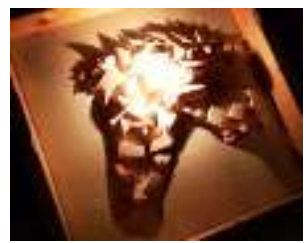

(ن) (

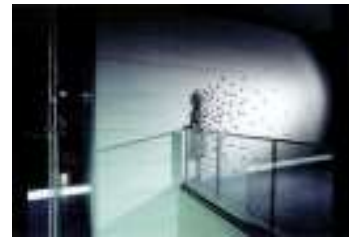

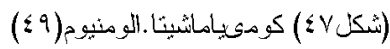

بزوايا من الإزتفاعات والإنخفضاث وزوايا الميل المختلفة لنشكل مع الضوء والسطح المثبته عليه، علاقات ظلية تتجمع لتؤدى الثكل الظلى المطلوب التعبير عنه،(ثكلوحء) ركزّت الفنانة كومي على الثكل الجسدي للإنسان من خلال إظهاره كظل، ويتضح عدداً من الوجوه استخدمت فيها أوراقاً قابلة للطي من جهة واحدة لثبرز من خلاله وضعية الظل مع إستاط مثثن للضوء من الجهة المقابلة وهذه الوجوه الظلية هي كثف حقيقي لوجوه الواقع البشرية التي يشوبها الزيف والثزوير والنفاق، فهي وجوه تجعل من (AmeSea Database - ae - April- 2021- 0481) 
أصحاب الأقنعة أكثر وضوحاً وعرياً عبر ضوء الثمس، فالثمس هي رمز للحقبقة وفضح للظلمة، وهي

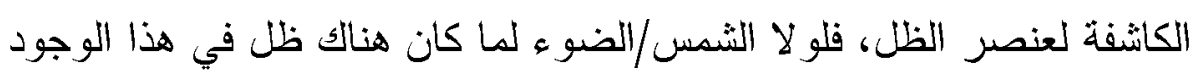

د- الادمج • اقى ينم دمج الرؤية ما بين العناصر الثكلية وصورة الظل . بحيث يكونون مكلين لبعضــهم

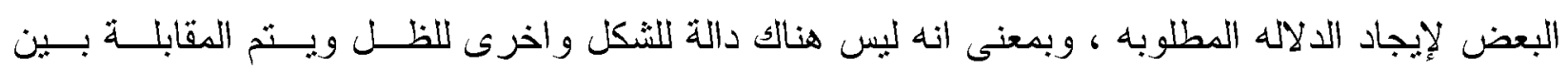

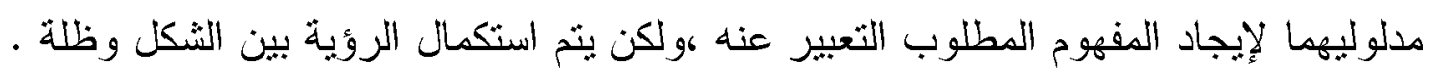

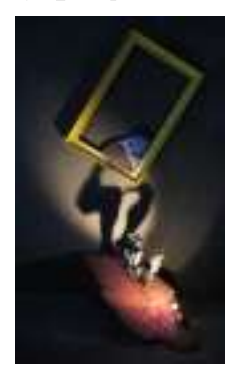

(نشكل 0) دايت ويجمان .خامات مختلفة . ضوء (rV)

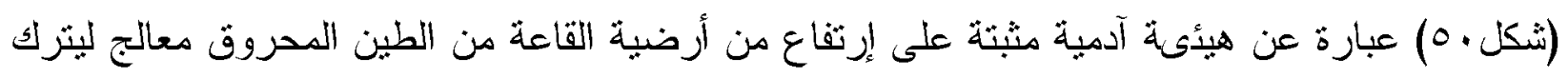

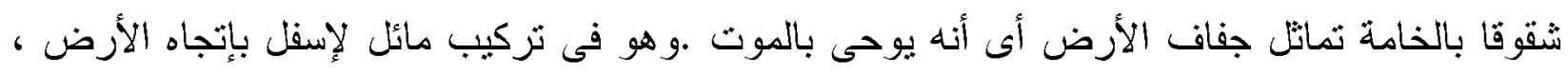

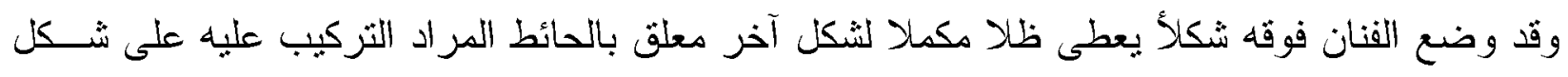

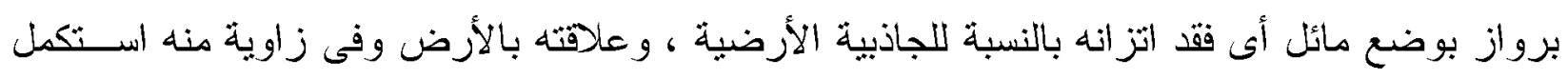

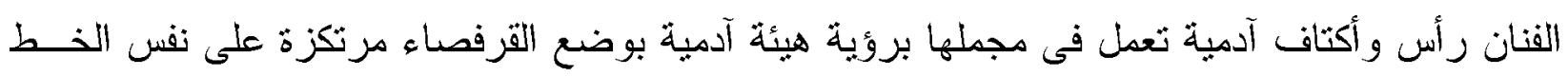

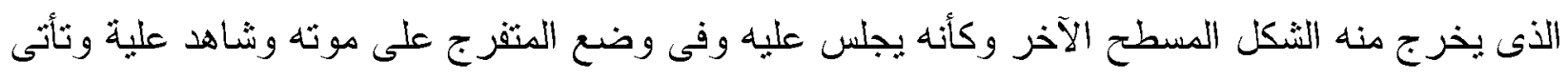

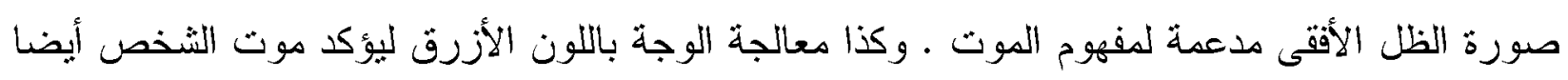

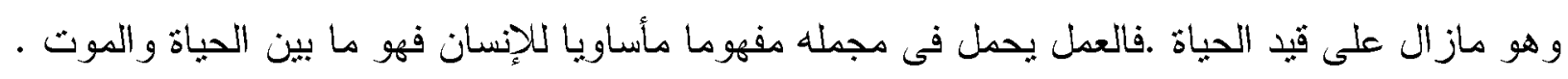

ه- التفريغ.أو مرشحات الضوء لرسم الظله على أوجه الجدران ، فعند استخدام الإضاءة الإصطناعية

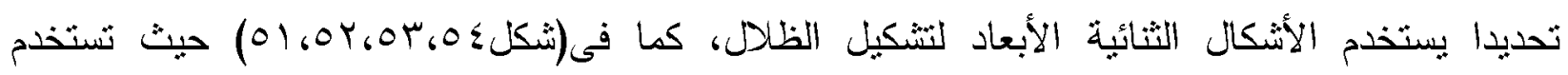
لوحات ثنائية الأبعاد محفور فيها أثكال الظلال المراد التعبير عنها ،وعن طريق تجميع تلك الظلدل برؤية

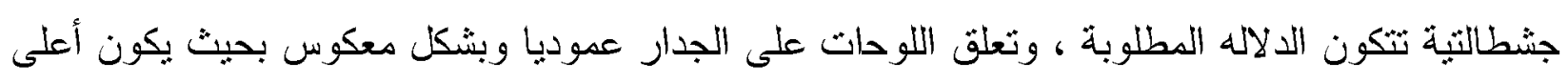

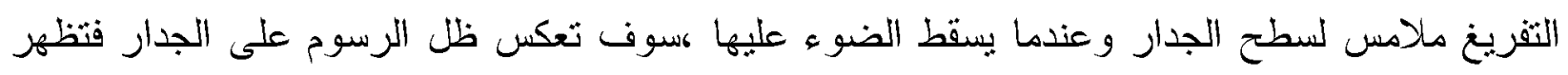

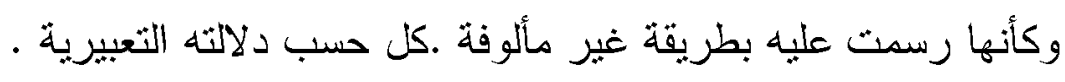

(AmeSea Database - ae - April- 2021- 0481) 


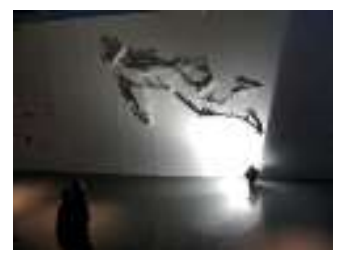

(ن)

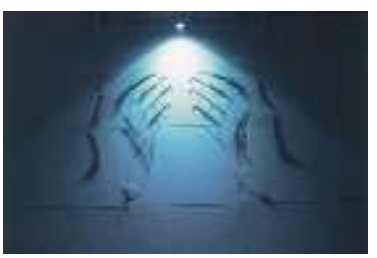

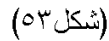

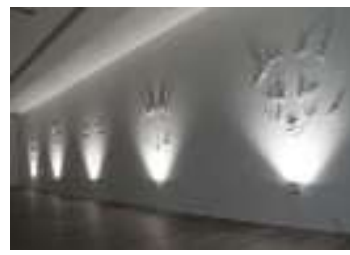

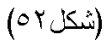

صور لأجزاء تقصيلية من عطل الفنان فابيزو كورينيلى.نحاس.ضوء(0)

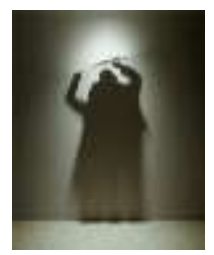

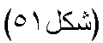

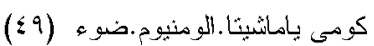

ومن خلال ما ثقدم تصبح فلسفة الإختلاف تعتمد من الأساس على المغايرة البصرية. فمنطق الظـلـ فـي الفن البصري ،أن الثكل لا بشبه ظله أبداً، والظل بكمن حقيقتة في الإختلف .

و -الظل متعدد الصور (ببرامج الجرافيك ثلاثية الأبعاد) .حيث يكون هنالك مدخلات لعـدة صــور وعـن

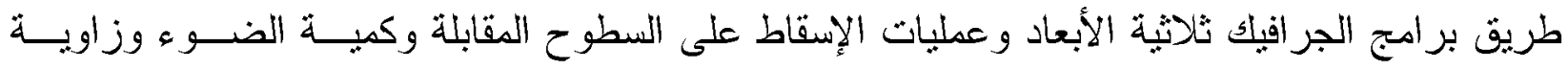
سقوطة بثم الجمع بين ظلدل عدة اشكال ،لتشكل زوايا من الرؤية في الشكل الواحد أى من عدة اتجاهات

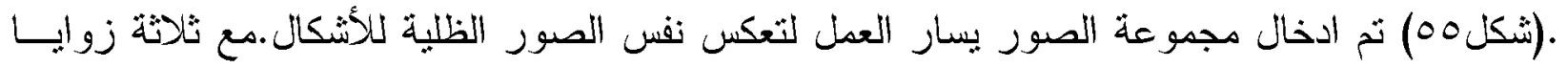

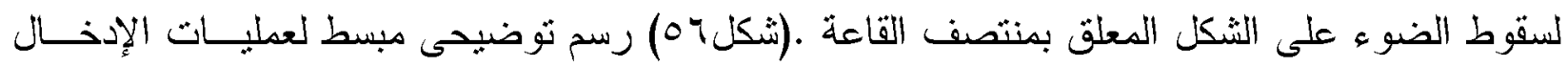
والتعديل • (شكل VV) زوايا لعمل نحتى منعدد الظلال لشخصياث كرنونية معروفة .

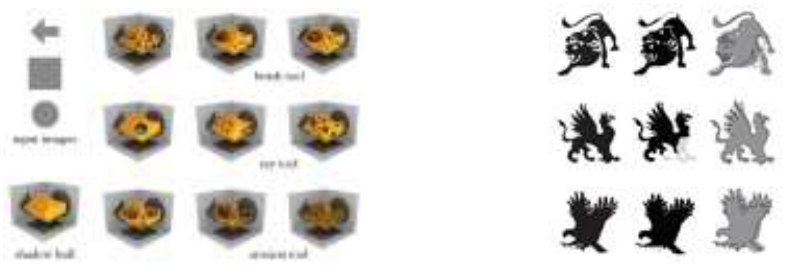

(شكل (07) رسم توضيحى لعمليات ادخال الصور وصنع الظل (9)
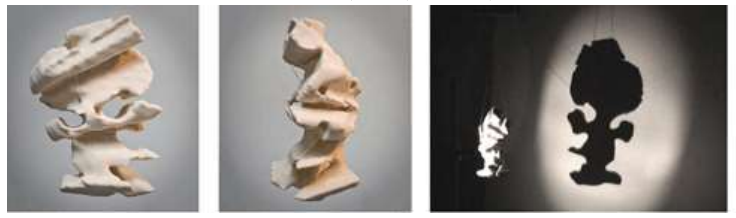

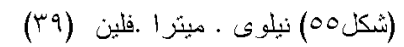

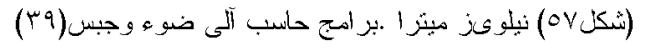

ج-المفارقة: أي أن الدال يفارق صوريا المدلول بـــالرغم أنـه ضمنيا لازم له، أى وجود الظل مع إنعدام وجود الثــكل أو وجود الشكل مع إنعدام الظل. مثلا فإن صورة دو امات الهو اء الحلزونية المتشكلة خلف أطر اف أجنحة الطائرة يمكن تكــون "دالة" على الطائرة "المدلول" رغم أنها لا نتبه شكل الطائرة في أى لى شئئ • "إن شكل العلامات فارغ ولكنه حاضر ومعناه غائب لكنه مليء ، وان الغياب في الواقع حضور، 


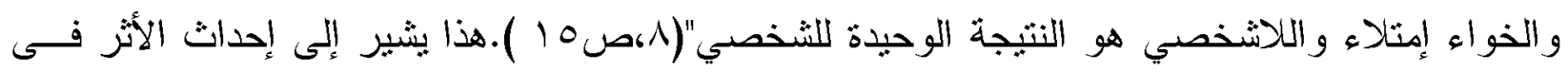
النفس خلا التجربة الثعورية المعاشية.

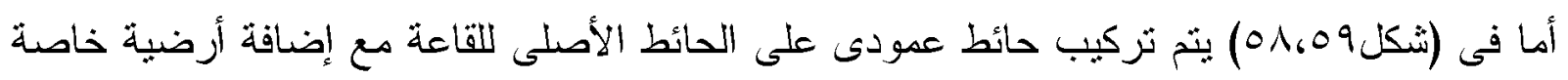

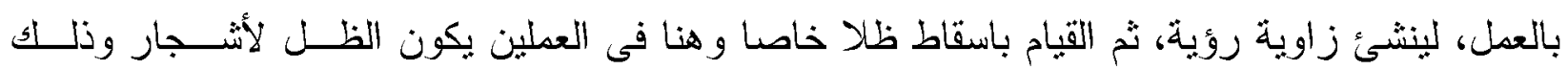

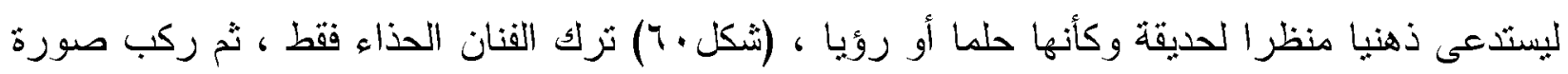

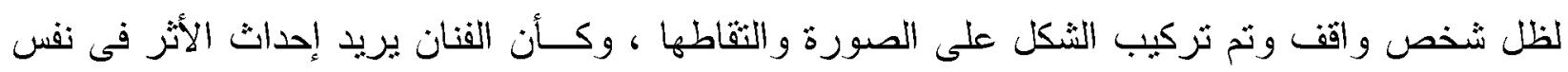

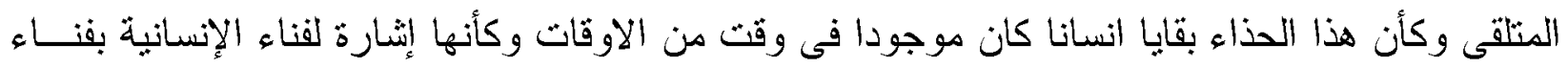
الجسد المادى للشكل

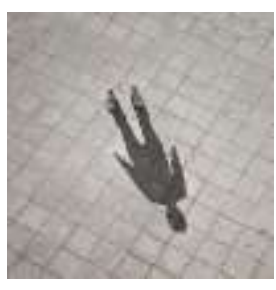

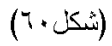

بول اوبيدا هيزفيس.حذاء.انعكاس صورة (100)

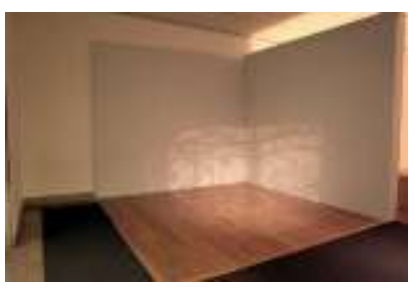

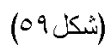

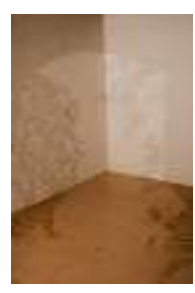

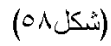

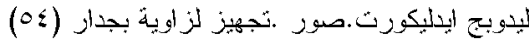

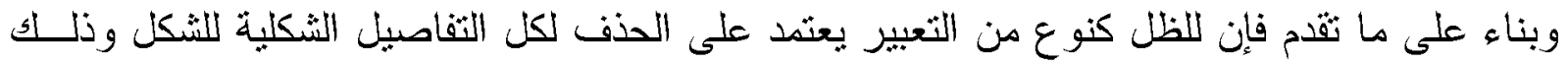

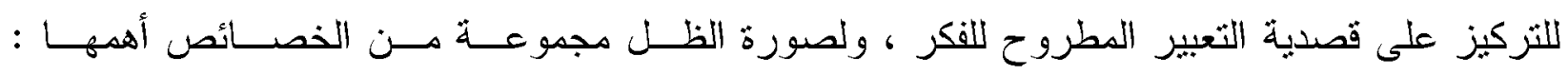
- التثكل والتحريف: فهي تتشكل بهيئات مختلفة، مما يؤدي لإختلاف المعنى وبالتالي إمكانية التحريف.

- الخداع وقابلية التأويل: كصورة المغنى أو المرأة.

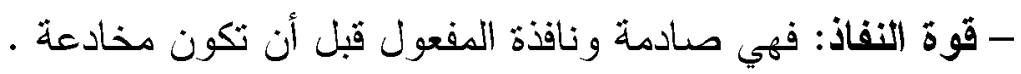

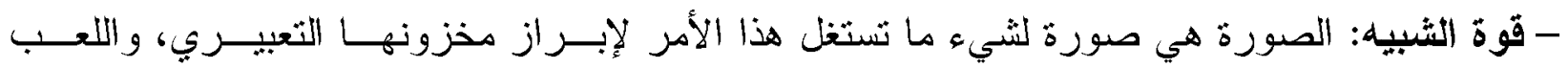
بالدلالات.

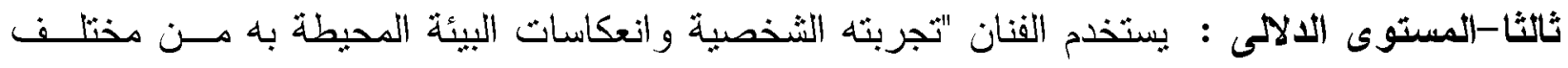
جو انبها الإجتماعية و النفسية وغيرها ،ويعاود تثكيلها بالرموز و الإشار ات و العلامات الفنية الثكلية محقةاً

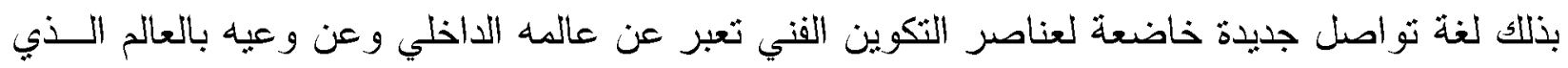

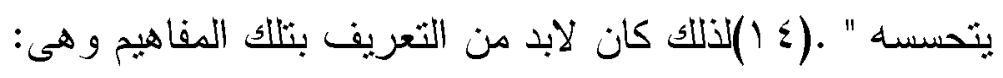

(AmeSea Database - ae - April- 2021- 0481) 
- الأيقون:عبارة عن "علامة نمتلك الخصائص الثي تجعلها دالة ششريطة أن يثبه هذا الثـــيء ويكـون

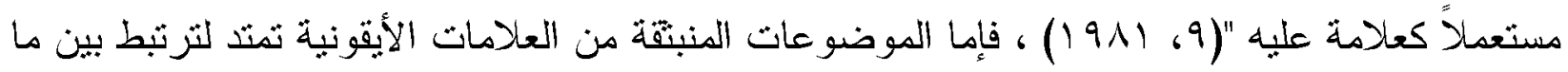

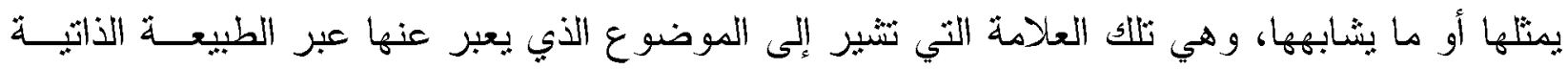

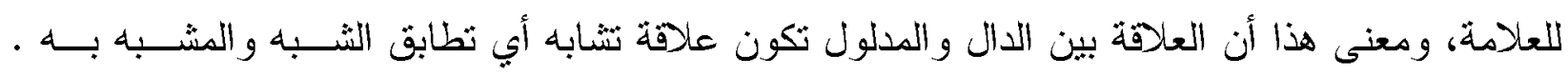

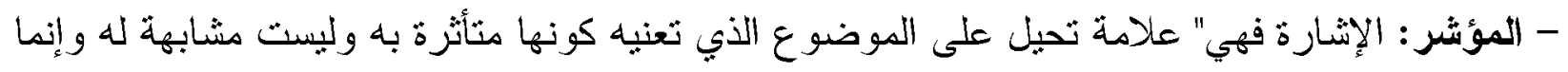

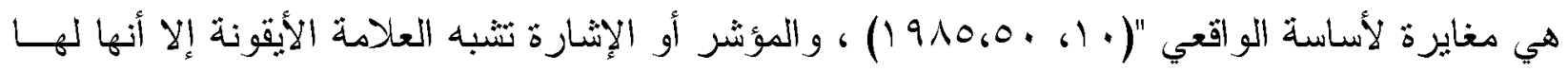

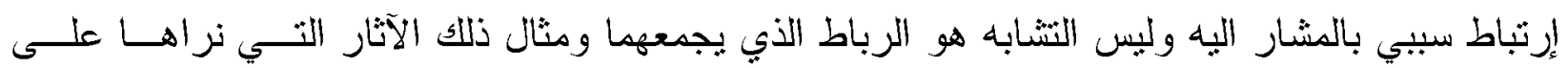

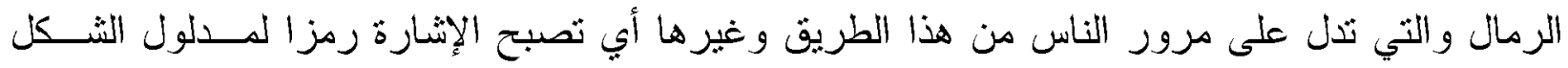
الأبقوني الزمان

- الرمز: و تكون العلاقة فيه علاقة اثفاقية عرفية بحيث " تحيل العلامة إلى الثيء الذي تثير إليه بفضل

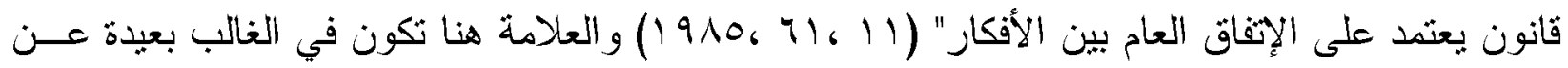

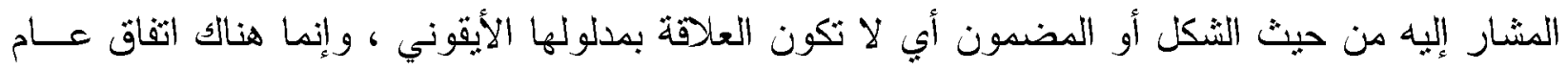

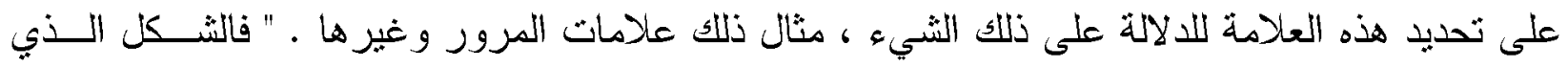

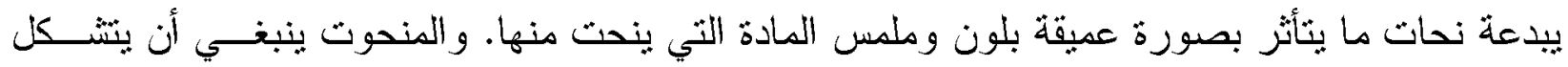

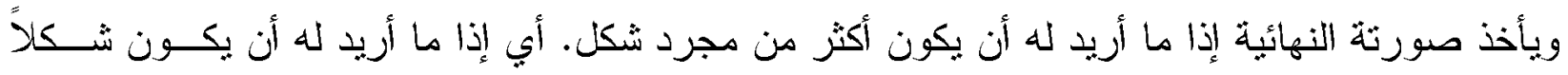

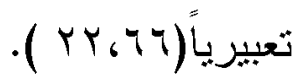
إنتاج الدلادة للظل داخل التكوين النحتى يتوقف على مستويين هما :

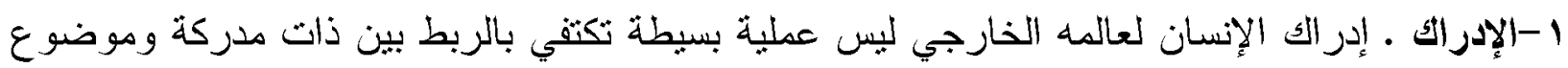

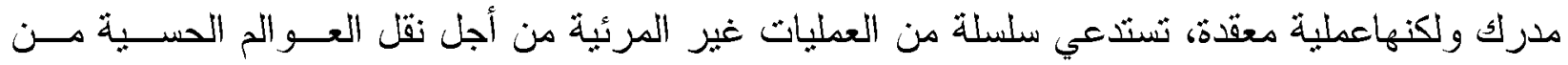

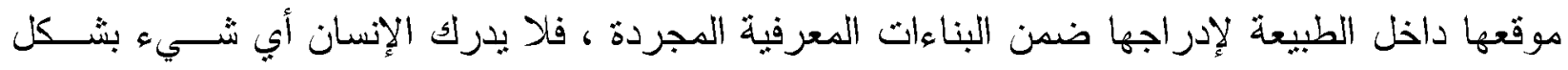
مباشر • "فالإدر الك والتذكر يقتضبان استحضار البنية الإدر اكية لمجموعة الصور التي تلثقطها العين ،ضمن

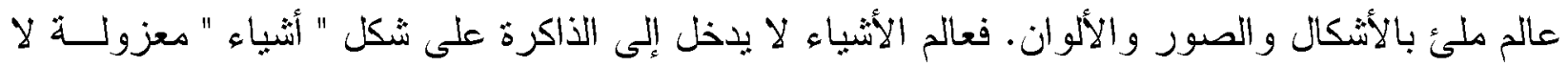

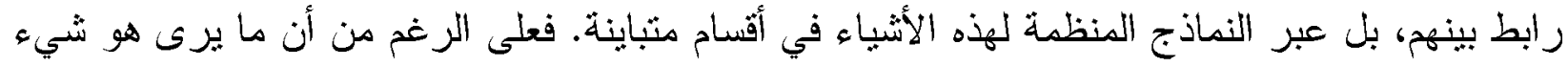

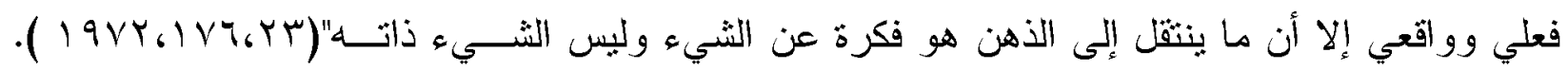

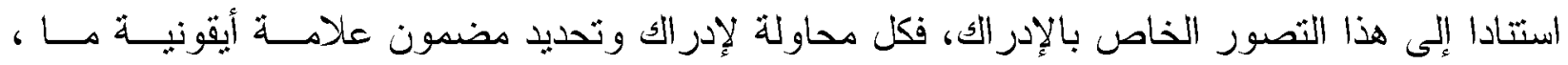
تقتضي إلماما بمعرفة سابقة مفتوحة على خبر ات متعددة. ويعود هذا الأمر لسبيين :

(AmeSea Database - ae - April- 2021- 0481) 
- إن ما تدركه العين هو علامات لا موضوعات. - إن العلامة الأيقونية لا تدل من تلثاء ذاتها، فالمعنى داخلها يستدعي استحضار التجربة الثقاف عافية كثرط أولي بممكنات إيجاد الدلاية . الذات المبصرة تجزئ المعطى البصري وتتظمة داخل أنثكال لتجعل منه كيانات دالة. وبعبارة أخرى،

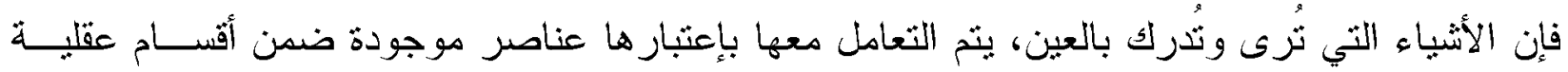

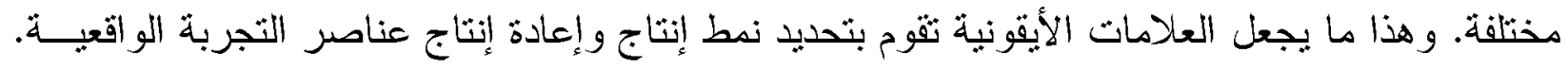

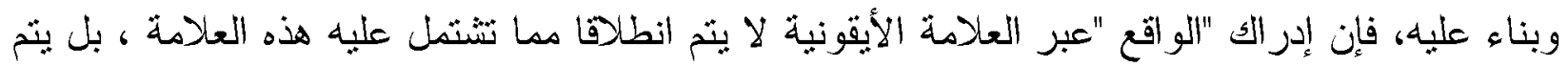

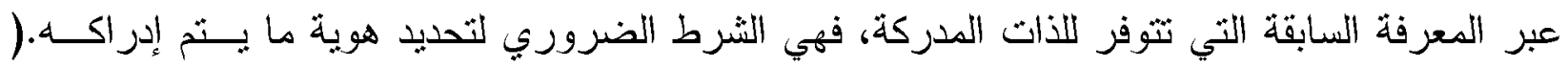

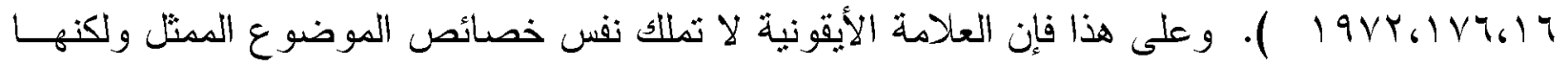

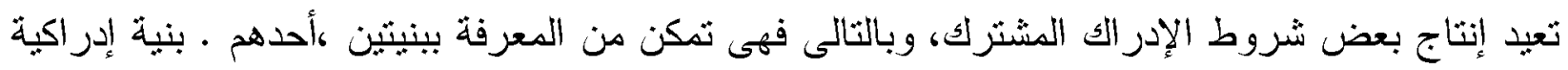

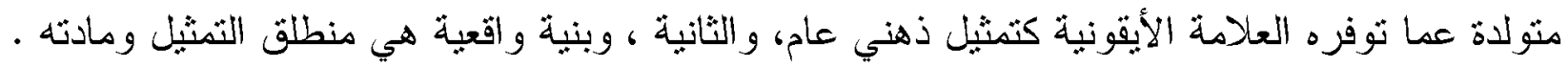

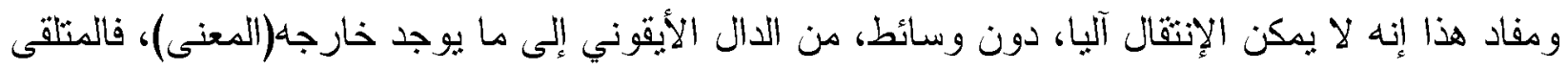

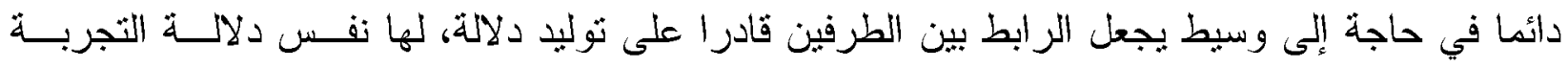

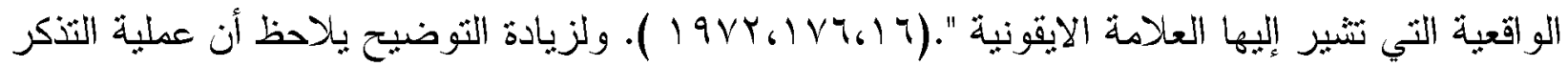

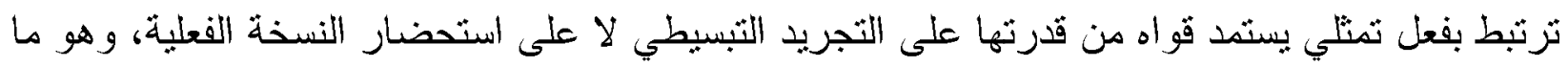

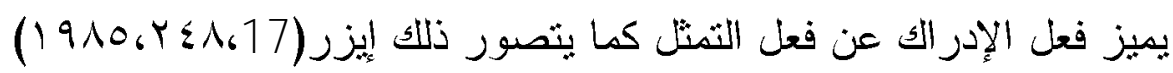

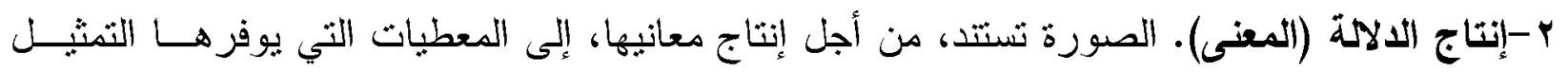

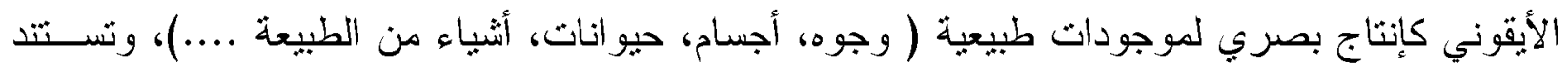

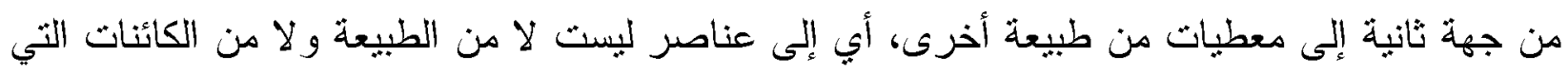

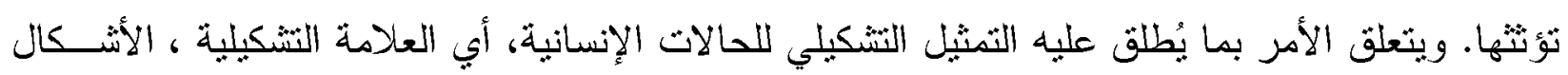

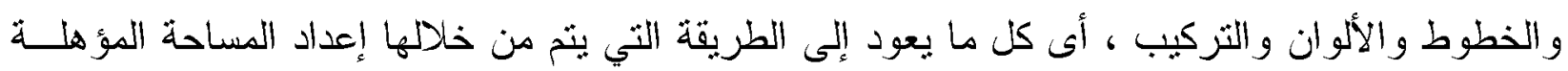
لإسنقبال الإنفعالات الإنسانية مجسدة في الأشكال و الأنشياء و الكائنات.

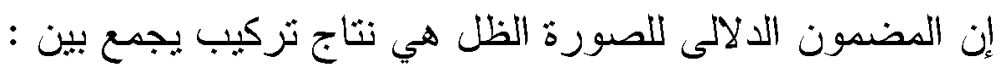

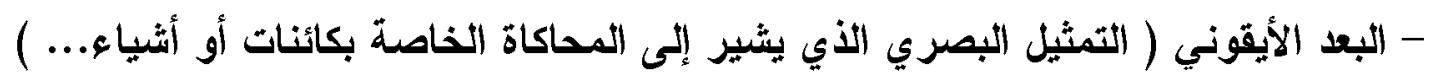

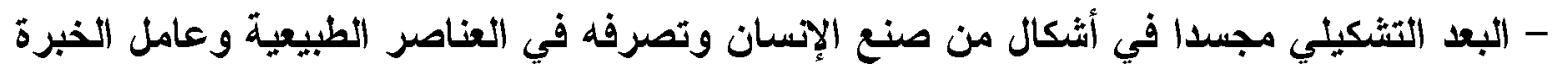
الناتج عن كم من التجارب.

(AmeSea Database - ae - April- 2021- 0481) 
بما أن الصورة الظلية هي واقعة بصرية ، فإن الوحداث الثكلية المتنوعة تفترض، إدراكا كليا للموضوع الذي تثدمه الصورة الظلية. نلاك الوحدات الثكلية هي بنيات يجب اعتبار ها معطيات أولية ، فالثكل بما له له من موقع واتجاه وحجم. يسندعى مضامين بعينها. فموقع الثنكل واتجاهه وحجمه عناصر أساسية في فهم

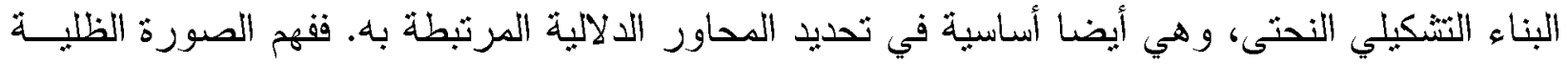
المرنبطة بقدرة المنلقي على القبام بالتنسيق بين مجمل المكونات البصرية للعمل الفنى.ويمن توضيح ذلك

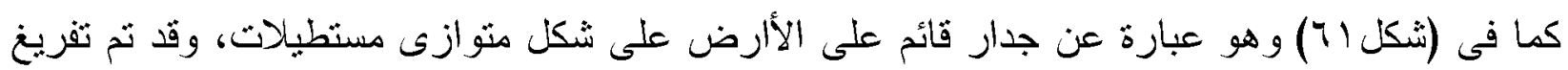

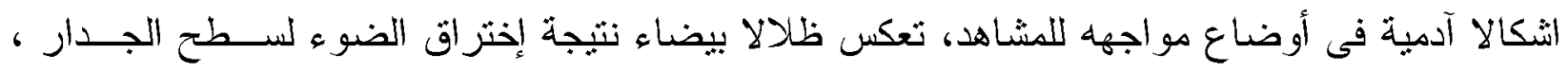

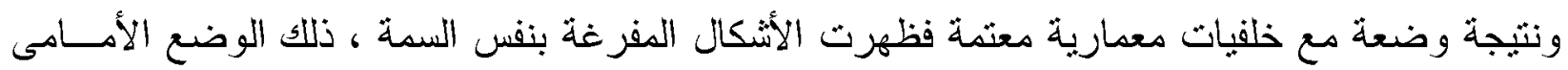
قد يدعو المشاهد إلى المشاركة ، كما قد ثثير عند المتثرج شعور البالتحدي والمجابهة. هذا الوضع يوضع

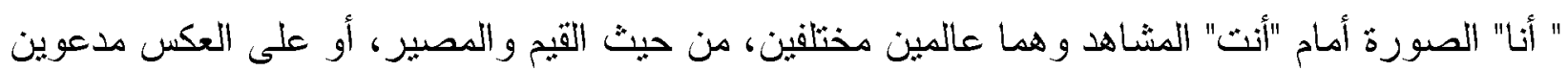

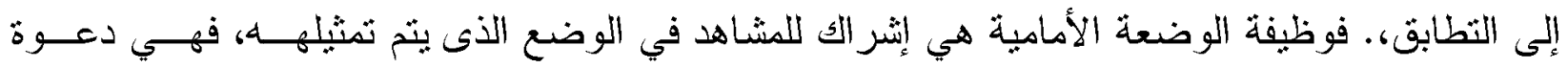
صريحة إلى تبني القبم الني بمثلها العمل الفنى وكأن ثلاك المجموعة الموجودة بالعمل الفنى ثدعو المشاهد

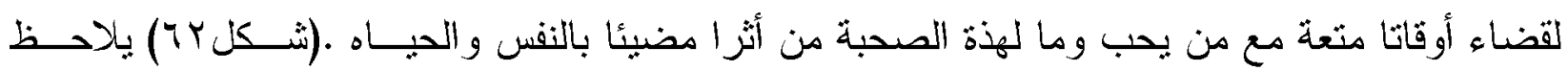

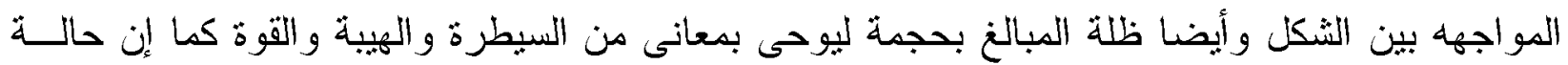
الثبات تدعو المشاهد للتفكير المشوب بالقلق كما تعطى دلاله عن التربص . الخوف هذا ما يخالف الوضع

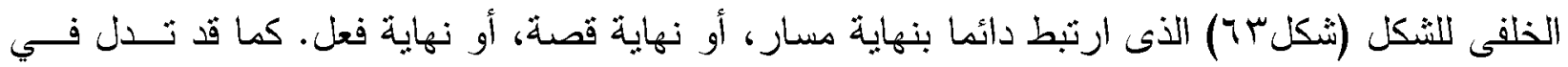

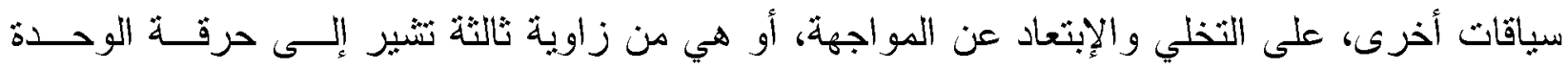

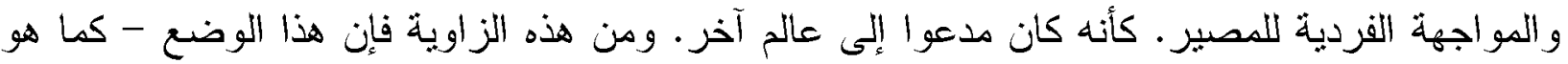

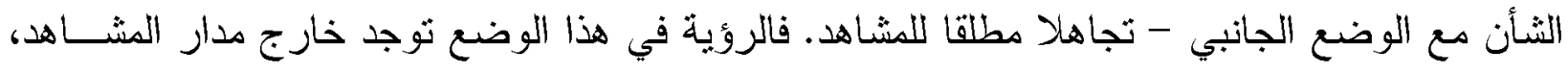

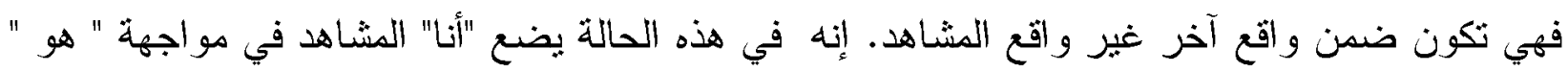

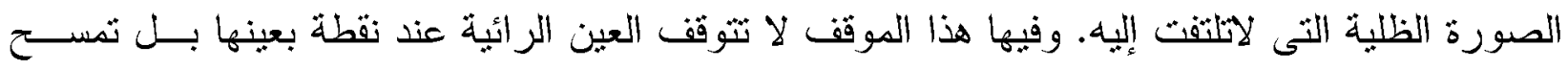

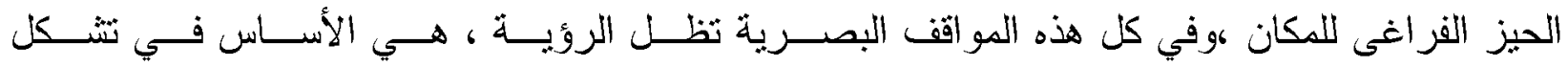

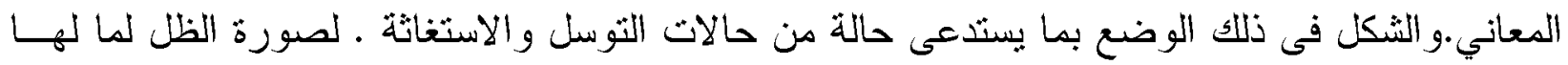
من حجم ووضع اكبر واتجاه به نوع من التثابل والمواجهة مما يعطى دلاله على تلقى المصبر المحتوم •

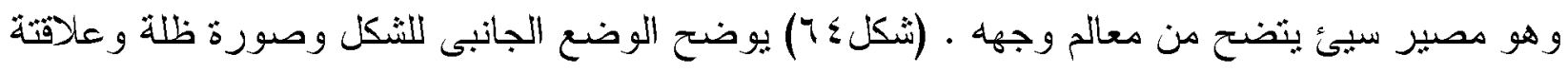

(AmeSea Database - ae - April- 2021- 0481) 
بالمشاهد فى اثيان المعنى ـ كما إن دلاله الوضع الحركى المتقابل لبعضه يوحى بمعانى الخصومه فكـلـ

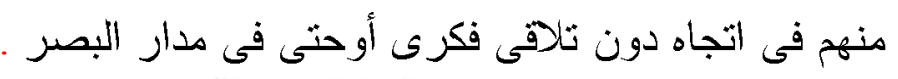

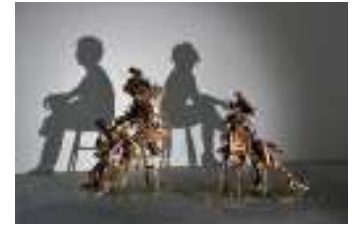

(ش) ( (

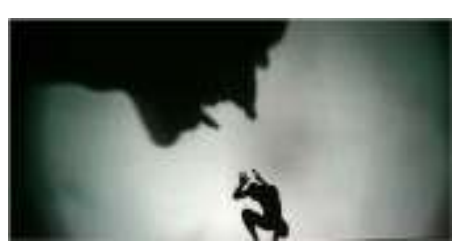

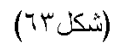

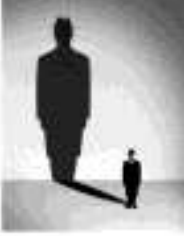

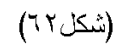

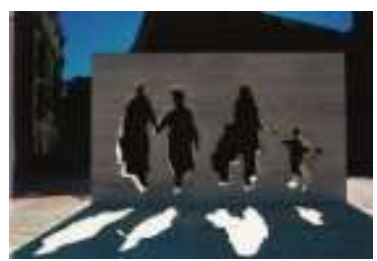

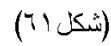

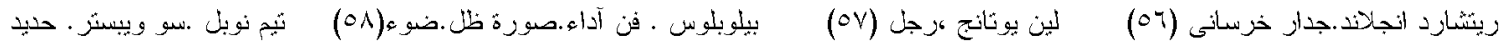

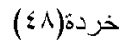

أن هذا الثواصل بين المشاهد والمكونات البصرية للعمل الفنى مشروط بالقصدية، وإرادة الفنان في التأثير في الغير، إذ لا يمكن للعلامة أن نكون أداة التواصلية القصدية ما لم نشترط القصدية التواصلية

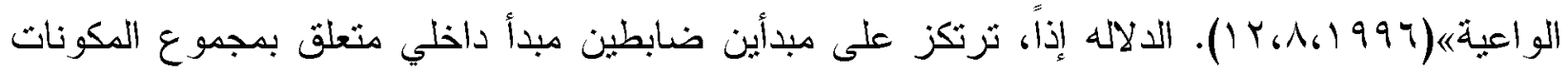

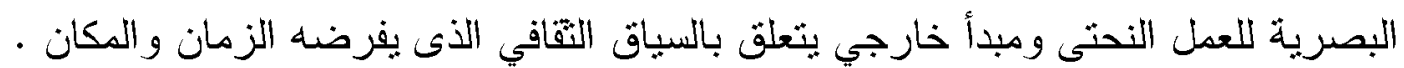
رابعا- المستوى الفكري والمعرفي والأيديولوجي لنسي إن البنية الداخلية أى المكونات البصرية للعمل الفني تضعه في علاقة خاصة، مع نظام القيم الموجود في

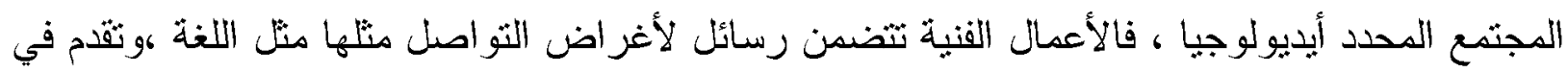

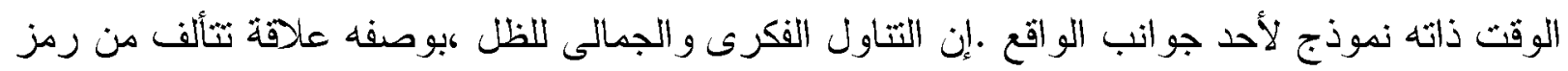

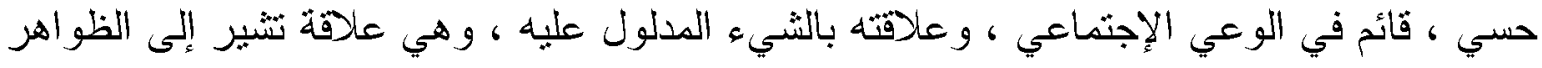

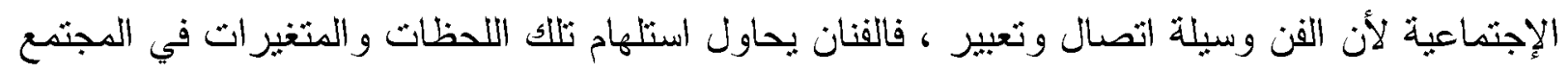

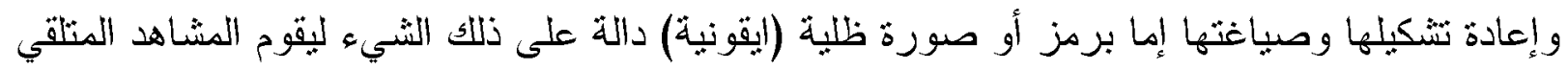

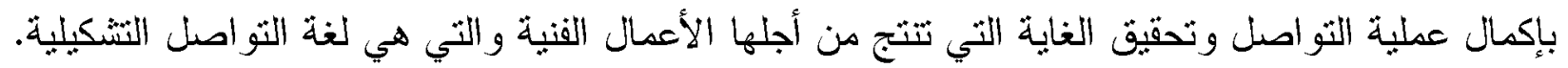

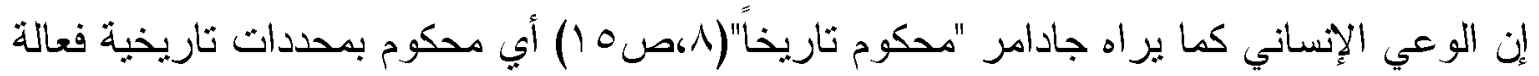

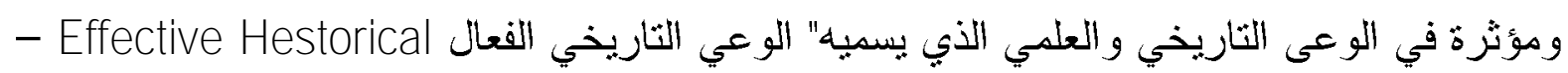

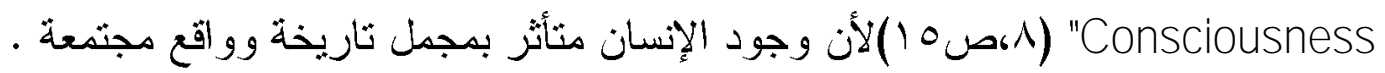

(AmeSea Database - ae - April- 2021- 0481) 
النتائج

يمكن تحديد أهم وظائف العناصر المشكله للظل بما بلي: ا-إضافة عناصر جديدة من المكونات البصرية، يكون له من التأثير، ما بضاهي ثأثير الثكل ، مهارة . . ץ- التغييز من القيمة الضوئية و اللونبة لبعض العناصر الثــــلية، مما يؤدي إلى تغبيز صفاتها الحقيقية الظاهرية. ب-الإيهام والتشويق . فبإمكان الصورة الظلبة أن تعطي انطباعات غير حقيقية ـ قد تكون أكثز جمالا من استخدام العناصر الحقيقية فرؤية ظل أحد الأشكال ، دون التمكن من رؤية الثكل الحقيقي أكثر تشويقا من رؤيتة كما هو في الطريقة المعتادة. ع - الظل هو دالة للثكل في نفس الوقت الذي يكون فيه الثكل دالة للظل. ه- ان المغايرة ومفارقة في العلاقة بين الثكل وظله بمكن استخدامها لتوليد لأشكال نحتية ذات عناصر مستحدثة. ج- هنالك عدة آلبات يمكن استخدامها ـ لتشكيل الظلال و إيجاد مداخل جديدة للتفكير . - التوصبيات

1 - ضرورة الإهنمام بالظل بإعثباره عنصر ا نشكيليا لا بقل أهمية عن باقي العناصر المادية . ب- ضرورة البحث عن آلبات تكوين الظلال بطرق مختلفة ومستحدثه لما له من أبعادا تعبيرية .

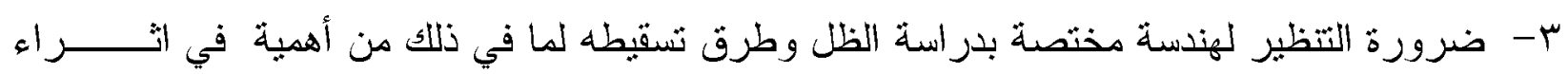
العمل الفني لنكون اتجاة مستحدث لتدريس النحت بكلية التربية الفنبة 4 - استخدام لآلية العكسية في إنتاج الإشكال انطلاقا من الظلال التي ثولدها وليس إنتاج الظلال اعتمادا على الأشكال التي تسقطها قد يؤدي ذللك الى إنتاج اتجاه معرفي جديد متخصص في تشكيلالظل.

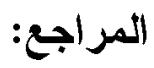

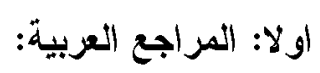
1- روبرت برنا سكوني: هانز جيورج جادامر ، ترجمة. سعيد توفيق المجلس الاعلى للتقافة ، مسقط 999 19 ص ص

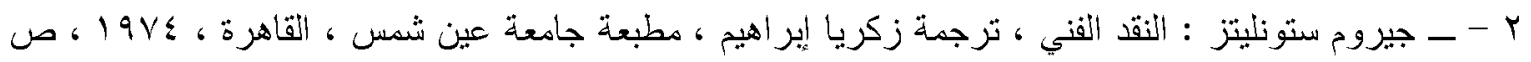
rrq- 190 ب-_ كيروزويل (أديث) : عصر النبيوية، ترجمة. جابر عصفور، دار الثيؤون الثقافية العامة ، مطبعة آفاق عربية،

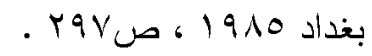

(AmeSea Database - ae - April- 2021- 0481) 


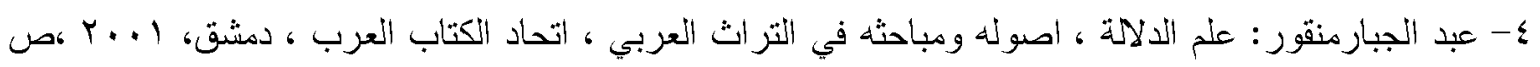

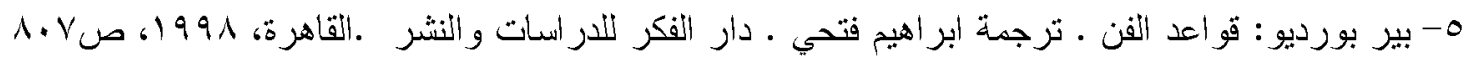

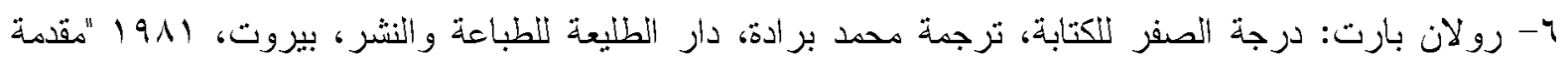
المترجم". V- تودروف: الادب و الدلالة، ترجمة محمد نديم خشنة، طا مركز الانماء الحضرب، ، طلب 994 1، صبا.

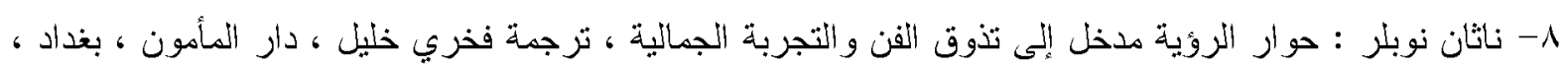
.

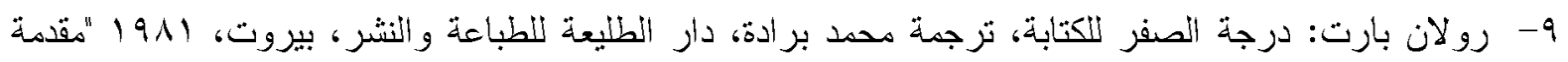
المترجم".

• - عبد الله الغذامي. الخطية و التكفير من البنيوية الى التتريحية قراءة نقدية. النادي الادبي التقافي جدة، 0.0 .1910

1ا- كاسير. فلسفة الاشكال الرمزية. ترجمة كمال اسطفان، في مجلة العرب و الفكر العالمي عدد ب مركز

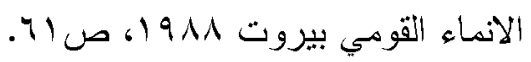

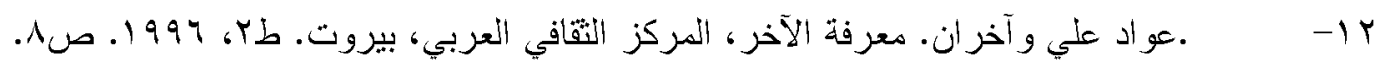
ثنانيا: المراجع الاجنبية .

1 - Suzanne K. langer. Problems of Art New York: Charles Serlbners Sone. 1957. P.p. 27-43 14-http://saidbengrad. free. fr/ar/artl. htm. pdf

15- Niloy J. Mitra IIT Delhi / KAUST Mark Pauly ETH Zurich. ShadowArt_sigA_09.PDF-Reader 17 -Umberto Eco : La structure absente, éd Mercure de France, 1972. p. 176

17- Wolfgang Iser. esthétique, éd Mardaga, : L'acte de lecture, théorie de l'effet، 1985, p 248

ثالثا:المواقع الإكترونية .

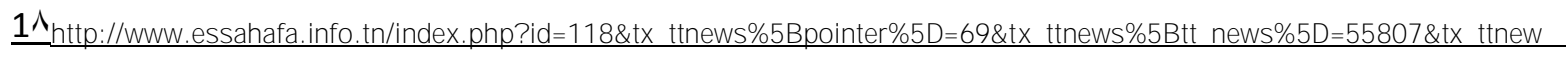

s\%5B backPid\%5D $=33 \& \mathrm{cH}$ ash $=1$ ce $4603 \mathrm{f} 29$

الخطاب البصري وسلطة الصورة في الفن المعاصر طه الليل II 1 .

19-http://ask.fm/maged3lgmal

21-http://www.al- jazirah.com/culture/2015/19122015/fadaat26.htm

22-http://www peregabriel.com/aveomaria.article.php?=id1341

23-http://www. quranm.com/?/quran/article/2675/\%D8\%A7\%

24.http://mawdoo3.com/\%D9\%83\%D9\%8A\%D9\%81_\%D8\%AA\%D8\%AA\%D9\%83\%D9\%88\%D9\%86_\%D 8\%A7\%D9\%84\%D8\%B8\%D9\%84\%D8\%A7\%D9\%84

"Young astronomer captures a shadow cast by J upiter" ‘Discover Magazine. $+\cdot 11-11-1 \Lambda$ ،

(AmeSea Database - ae - April- 2021- 0481) 
25-http://ar. wikipidia. org/wiki/

$$
\text { ثالثا :مراجي الصور - مواقع إلكترونية }
$$

26-https://aparalleluniverse.wordpress.com/2006/09/26/national-geographic-camels-and-shadows/ $r \vee$ - http://mymodernmet.com/diet-wiegman-light-sculptures/

Top of Form Incredibly Detailed Shadow Sculptures by Diet Wiegman

By Pinar on March 22, 2013

Y^- https://www.demilked.com/shadow-book-motion-silhouette/ Interactive 'Motion Silhouette' Book Uses Light And Shadows To Bring Stories To Life. Published 3 years ago rq-http://www.designboom.com/art/bohyun-yoon-structure-of-shadow bohyun yoon: structure of shadow. jul 23, 2010

30- http://sharronokines. weebly.com/blog/category/bali .2013

31-http://www.australiasgoldenoutback.com/things-to-do-australianoutback/Art_culture_and_history/Gormley_Sculptures.-Gormley Sculptures

32- https://www. pinterest.com/Spazzaneve83/lighting- design/

33- http://www. lydiagreer. com/art- film/- on- this- spot

34- voltashow. com/archive/volta2/exhibitors/spencer.../fred-eerdekens

35- pinbrowser.com/photo/177681147768659049

r\%- http://artistaday.com/?p=20210- Moto Waganari Eschborn, Germany

37- https://www. fludit. com/inspiration/the- shadow- art- photos- by- paul- villinski.html 38-http://weburbanist. com/2015/03/25/drawing- with- darkness- 24- incredible- works- ofshadow- art/

40- http://datenform. de/016.html

§)- http://www.handimania.com/tag/paper/page/4/

42-https://www. thewinfieldcollection.com/print_catalog/People-Y Yard-Shadow- WoodcraftPatterns

« r- http://inhabitat. com/artist- li- hongbo- carves- butchers- knife- blades- into- delicate- naturescenes/

44- http://globalnews.ca/news/1071343/british- artist- marcus- levine- creates- stunningpictures- with- nail- art/

(AmeSea Database - ae - April- 2021- 0481) 
45- http://www. thisismarvelous.com/amazing- shadow- sculptures- by- tim- noble- and- suewebster/

46- http://inhabitat. com/british- artists- tim- noble- sue- webster- create- jaw- dropping- art- withshadows- and- found- objects/

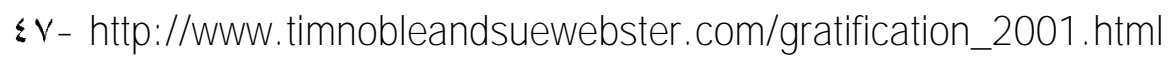

纟A- https://www. yatzer. com/Nihilistic- Optimistic- Tim- Noble- Sue- Webster- Blain- SouthernLondon

49- http://www. designboom.com/art/kumi- yamashita- interview- 03- 05- 2015/

50- http://www. 123inspiration.com/breathtaking- light- and- shadow- art- by- fabrizio- corneli/ o1- https://www. etsy.com/ca/listing/173598590/silhouette- shadow- artwomans

52- https://artintheheartofsummer. wordpress.com/2013/08/28/rashad- alakbarov- at- theazerbaijan- pavilion- 55th- venice- biennale/ or- http://www. zenmagnets.com/blog/22-5- magnet- shadow- winners- announced/ 54- http://www. edelkoort.com/editions/bloom- library/gallery- bloom16/ 55- https://petapixel.com/2013/01/16/photos- of- empty- shoes- with- shadows- and- reflections/ 56- http://mea- awards.gr/2013/01/richard- england/ ov- http://www. goodreads.com/quotes/672986- when- small- men- begin- to- cast- bigshadows- it- means

od- http://www. trendhunter.com/trends/pilobolus- dance- company- shadowland

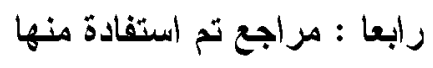

1-EWART, F. G. 1998. Let The Shadows Speak. Trentham Books. GAL, R., SORKINE, O., POPA, T., SHEFFER, A., AND COHENOR, D. 2007. 3Dcollage: Expressivenon- realisticmodeling. In Proc. of NPAR, 7-14

2- GALYEAN, T. A., AND HUGHES, J. F. 1991. Sculpting: an interactive volumetric modeling technique. In Proc. of SIGGRAPH, 267-274

3-KUTULAKOS, K. N., AND SEITZ, S. M. 1999. A theory of shape by space carving. Int. J ournal of Computer Vision 38, 307-314

(AmeSea Database - ae - April- 2021- 0481) 


\section{Handling intellectual and aesthetic shade in contemporary sculpture}

Summary: The shadow can be seen by eye but it is only realized from prolonged meditation. From perception of variables in nature, then realize it's existence in something else, that relates to a third absent fact, so the shade is an absolute evidence of the existence of the shade so the shade of the object is the evidence of an object oriented body. There are sculptural experiments carrying a thought of concept toward a variant visual concept of the concept of shadow. And from here the logical conceptual art in the idea of the variant shade was found. The shade that can be seen on the surface of the wall or on the ground is not necessarily the corresponding figure of the shade, and the shapeless can also impose the cancellation of the correspondence concept. And there lies the new concept of shadow in the world of art.

Through the dialectical relationship emerging between the shape form and the shape content, in addition to the shade image and what it reflects in an additive meaning. A formula is reflected in a decoding process which represents an analysis of the indicative and the resulting effect on the aesthetic dimension of the image of the shade of the object which in turn generate the intellectual dimension of the recipient, going through observation and analysis. And what the shock process caused to the thoughts and honor and this is a guiding role of the indicative field of the shadow image and its relationship to the form, and this field represents the indicative link between the visual components and their relationship to understanding the meaning.

The process of joining the shape with the shade has been formed between sensory and mental, material and non-material and between the visions of contemporary forms through multiple ways of construction. From the principal of diversity in unity of this approach stems fine aesthetic between sensory and fantasy. The material is selected through a shadow image and the physical sensory relationship is entirely absent, this is what makes him able to establish a tremendous creative energy supports visual culture and make the process of plastic lively and spontaneous and their offspring current time represents the vital area in which we search for a balance between intellectual, scientific, physical and sensory research questions lies in: what is intellectual and aesthetic dimension to carve shadows?, and this is for the possibility of benefiting from it in the field of research

(AmeSea Database - ae - April- 2021- 0481) 